Review

\title{
Hydrogen Production by the Thermophilic Bacterium Thermotoga neapolitana
}

\author{
Nirakar Pradhan ${ }^{1, \dagger}$, Laura Dipasquale ${ }^{2, \dagger}$, Giuliana d'Ippolito ${ }^{2}$, Antonio Panico ${ }^{3}$, \\ Piet N. L. Lens ${ }^{4}$, Giovanni Esposito ${ }^{1}$ and Angelo Fontana ${ }^{2, *}$
}

1 Department of Civil and Mechanical Engineering, University of Cassino and Southern Lazio, Via Di Biasio, 43, 03043 Cassino, FR, Italy; E-Mails: nirakar.pradhan@gmail.com (N.P.); giovanni.esposito@unicas.it (G.E.)

2 Istituto di Chimica Biomolecolare, Consiglio Nazionale delle Ricerche, Via Campi Flegrei 34, 80078 Pozzuoli, Napoli, Italy; E-Mails: 1dipasquale@icb.cnr.it (L.D.); gdippolito@icb.cnr.it (G.I.)

3 Telematic University Pegaso, piazza Trieste e Trento, 48, 80132 Naples, Italy;

E-Mail: anpanico@unina.it

4 UNESCO-IHE Institute for Water Education, Westvest 7, 2611-AX Delft, The Netherlands; E-Mail: piet.lens@wur.nl

$\dagger$ These authors contributed equally to this work.

* Author to whom correspondence should be addressed; E-Mail: afontana@icb.cnr.it; Tel.: +39-81-8675096; Fax: +39-81-8675340.

Academic Editor: Dr. Patrick Hallenbeck

Received: 1 April 2015 / Accepted: 22 May 2015 / Published: 4 June 2015

\begin{abstract}
As the only fuel that is not chemically bound to carbon, hydrogen has gained interest as an energy carrier to face the current environmental issues of greenhouse gas emissions and to substitute the depleting non-renewable reserves. In the last years, there has been a significant increase in the number of publications about the bacterium Thermotoga neapolitana that is responsible for production yields of $\mathrm{H}_{2}$ that are among the highest achievements reported in the literature. Here we present an extensive overview of the most recent studies on this hyperthermophilic bacterium together with a critical discussion of the potential of fermentative production by this bacterium. The review article is organized into sections focused on biochemical, microbiological and technical issues, including the effect of substrate, reactor type, gas sparging, temperature, $\mathrm{pH}$, hydraulic retention time and organic loading parameters on rate and yield of gas production.
\end{abstract}


Keywords: thermophilic bacteria; fermentation; hydrogen; lactic acid; carbon dioxide; biomass; renewable energy; process kinetics; energy carrier; green-house gas

\section{Introduction}

Anaerobic digestion of organic material is regarded as a potential method for hydrogen $\left(\mathrm{H}_{2}\right)$ production from biomass [1,2]. Besides simple carbohydrates (e.g., glucose) or polymers such as starch and cellulose, the process utilizes a wide range of organic compounds as substrate, including organic wastes and agro-industrial matrices [3-9]. Considering that such residues are abundant, cheap, renewable and biodegradable, $\mathrm{H}_{2}$ production by fermentation of this material is potentially competitive over conventional process [5] and technically more feasible than other biological methods, including photofermentation and photobiolysis. Furthermore production of $\mathrm{H}_{2}$ from organic substrates is viewed as an environmentally friendly process because of its potential to yield clean energy while reducing waste and greenhouse gas emissions. Although a more detailed life cycle assessment of feedstock materials is required to fully understand the environmental impact of the whole process, the possible implications on climate change have prompted growing attention to the fermentative production of $\mathrm{H}_{2}$ in recent years [10].

Chemotrophic $\mathrm{H}_{2}$ production can be operated at mesophilic $\left(25-40{ }^{\circ} \mathrm{C}\right)$, thermophilic $\left(40-65{ }^{\circ} \mathrm{C}\right)$ or hyperthermophilic $\left(>80^{\circ} \mathrm{C}\right)$ temperatures [11-13], but the process in heated cultures benefits from thermodynamically favorable reactions $[14,15]$. Although metabolic activity sharply drops outside the optimum temperature range, increase of temperature accelerates reaction rates and offers a number of technical advantages including reduction of viscosity, improvement of mixing efficiency, reduced risk of contamination and no need for reactor cooling [16]. In addition, the high operating temperature enhances hydrolysis rate of complex substrates and, generally speaking, thermophiles can more effectively utilize complex sugars, e.g., cellulose, than mesophiles [17,18]. Furthermore, hyperthermophilic conditions suffer less from inhibition due to $\mathrm{H}_{2}$ partial pressure and, in the case of microbial consortia, are less sensitive to $\mathrm{H}_{2}$ consumers like methanogens [19,20].

In the last years, pure cultures of the hyperthermophilic eubacterium Thermotoga neapolitana has shown promising results for fermentative $\mathrm{H}_{2}$ production from several organic substrates [21]. In a recent paper [22], we have also shown that $T$. neapolitana can yield significant amounts of lactic acid without affecting $\mathrm{H}_{2}$ synthesis, thus offering novel applications for the fermentative process. Here we critically review the most recent data on $\mathrm{H}_{2}$ production by $T$. neapolitana and discuss the challenges and future prospects of $\mathrm{H}_{2}$ production using this bacterium.

\section{Taxonomy of Thermotoga neapolitana}

Originally isolated from shallow submarine hot spring nears Lucrino in the Bay of Naples in 1986 [23,24], T. neapolitana is a gram-negative bacterium that grows between 55 and $90{ }^{\circ} \mathrm{C}$ with an optimal growth temperature of $80^{\circ} \mathrm{C}[23,24]$. The species belongs to the order Thermotogales (Phylum Thermotogae, class Thermotogae) that have, until the recent report of Mesotoga prima [25], been exclusively comprised of thermophilic or hyperthermophilic organisms. The order includes an 
assembly of rod-shaped, non-sporulating bacteria that are characterized by an unconventional outer envelope called the "toga", which forms a large periplasmic space at the poles of each rod [26-28]. Although it has been shown that these regions could be involved in the formation of multicellular rods [29], the physiological role of the large periplasm remains unknown. Thermotogales also synthesizes many polysaccharide hydrolases, some exposed on the cell surface, that allow utilization of diverse sources of carbon [30-39].

The phylogenetic position of Thermotogae is still unresolved, even if many studies agree to place members of this phylum among the deepest branches of bacteria, and, thus, as prime candidates for evolutionary studies [21,40]. Based upon different phylogenetic approaches, the class Thermotogae is divided into three orders (Thermotogales, Kosmotogales and Petrotogales) containing four families (Thermotogaceae, Fervidobacteriaceae, Kosmotogaceae and Petrotogaceae) and 10 genera (Thermotoga, Thermosipho, Fervidobacterium, Geotoga, Petrotoga, Marinitoga, Thermococcoides, Kosmotoga, Oceanotoga, and Defluviitoga). The genus Thermotoga currently includes eleven species, i.e., T. maritima, T. neapolitana, T. thermarum, T. elfii, T. subterranea, T. hypogea, T. petrophila, T. naphthophila, T. lettingae, T. caldifontis, and T. profunda, that thrive in marine hydrothermal vents, oil reservoir sites and volcanic springs [21]. Recently, Bandhari and Gupta [41] proposed to split the current genus Thermotoga into two evolutionary distinct groups. According to this last classification, the original genus Thermotoga retains only the species T. maritima, T. neapolitana, T. petrophila, T. naphthophila, Thermotoga sp. EMP, Thermotoga sp. A7A and Thermotoga sp. RQ2 while the other Thermotoga species (T. lettingae, T. thermarum, T. elfii, T. subterranea and T. hypogea) belong to the new genus Pseudothermotoga [41].

\section{Dark Fermentation Pathway in Thermotoga neapolitana}

Chemotropic production of $\mathrm{H}_{2}$ is a respiration process using $\mathrm{H}^{+}$as electron acceptor. The biochemical synthesis by bacteria of the genus Thermotoga entails catabolism of carbohydrates even if different members of the genus have the ability to use a large variety of substrates that, for example in T. elfii, include also sulfur compounds [42]. As in the related species T. maritima [43,44], T. neapolitana harvests energy mainly by glycolysis via the Embden-Meyerhoff pathway (EMP) [45]. EMP is the most common route for oxidation of glucose (and other hexoses) and supplies energy (ATP), reducing equivalents $(\mathrm{NADH})$ and pyruvate, that undergoes terminal oxidation (acetate) or is used for biosynthesis (e.g., acetyl-CoA). According to the classical model of fermentation, generally referred to as Dark Fermentation (DF), 4 mol of $\mathrm{H}_{2}$ can be theoretically produced per mole of consumed glucose [46]. This molar ratio between $\mathrm{H}_{2}$ and glucose is usually referred to as the Thauer limit and represents the highest yield that can be achieved by a sugar-based fermentation by thermophilic bacteria. As fermentative $\mathrm{H}_{2}$ production is a mean to dispose of electrons, there is a direct relationship between the biogas yield and the type of the organic products that are concurrently released during the process. Yield is optimized only when all glucose is converted to acetate because NADH and electrons are fully consumed to produce the energy carrier (Equation (1)). On the other hand, in a redox neutral process, no $\mathrm{H}_{2}$ is produced when lactic acid is the organic product released in the medium (Equation (2)).

$$
\mathrm{C}_{6} \mathrm{H}_{12} \mathrm{O}_{6}+4 \mathrm{ADP}+4 \mathrm{Pi} \rightarrow 2 \mathrm{CH}_{3} \mathrm{CO}_{2} \mathrm{H}+2 \mathrm{CO}_{2}+4 \mathrm{H}_{2}+4 \mathrm{ATP}+2 \mathrm{H}_{2} \mathrm{O}
$$




$$
\mathrm{C}_{6} \mathrm{H}_{12} \mathrm{O}_{6}+2 \mathrm{ADP}+2 \mathrm{Pi} \rightarrow 2 \mathrm{CH}_{3} \mathrm{CH}(\mathrm{OH}) \mathrm{CO}_{2} \mathrm{H}+2 \mathrm{ATP}+2 \mathrm{H}_{2} \mathrm{O}
$$

As shown in Figure 1, acetate production is driven by formation of additional ATP but, when $\mathrm{H}_{2}$ accumulates and consumption of NADH stops, pyruvate is diverted away for the synthesis of other organic substrates, mostly lactate that is produced by lactate dehydrogenase (LDH) with the concomitant oxidation of NADH. Lactate levels reported during fermentation by Thermotoga species vary from trace amounts up to levels rivaling those of acetate [44,47-49]. Low levels of alanine and ethanol have been also reported in T. neapolitana $[21,45,50]$.

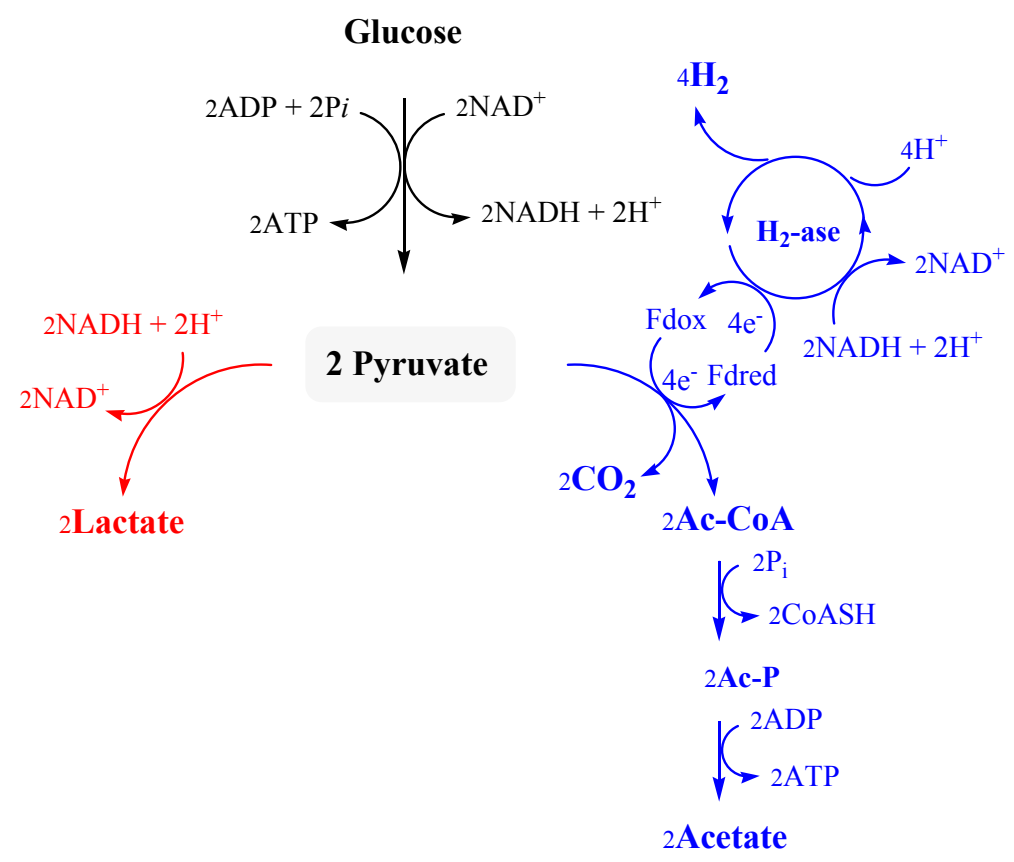

Figure 1. Streamlined biochemical pathway for fermentative $\mathrm{H}_{2}$ production, adapted from Reference [22]. Water is omitted for simplicity.

The mechanism behind the high $\mathrm{H}_{2}$ yields achieved by $T$. neapolitana is likely related to the unique characteristic of the heterotrimeric [FeFe]-hydrogenase that is present in the bacterium. Hydrogenases ( $\mathrm{H}_{2}$ ase) constitute a family of enzymes that efficiently reduce protons to $\mathrm{H}_{2}$ in many anaerobic microorganisms. Sequence analysis on the three proteins that form the $\mathrm{H}_{2}$ ase of T. maritima, which has more than $90 \%$ homology with that of T. neapolitana, suggests that the $\beta$ subunit is a flavoprotein that accepts electrons from $\mathrm{NADH}$, and the $\gamma$ subunit transfers electrons from the $\beta$ subunit to the catalytic $\alpha$ subunit. The catalytic site (the so-called $\mathrm{H}$ cluster) shows the most complex Fe-S structure characterized to date and requires the specific action of three highly conserved proteins to be assembled [51]. Despite the detailed knowledge of the active site, how the endergonic reaction of $\mathrm{H}_{2}$ production is accomplished under physiological conditions is not clear. In fact, the reduction of $\mathrm{H}_{2}$ ase by NADH is an energetically unfavorable reaction and the reaction is typically influenced by environmental conditions such as $\mathrm{pH}$, cell growth rate and $\mathrm{H}_{2}$ partial pressure. In many thermophilic bacteria and several Clostridium species, the transfer of electrons to proton ion by [FeFe]- $\mathrm{H}_{2}$ ase requires the presence of NADH-Ferredoxin oxidoreductase (NFOR). In this reaction, it is suggested that the oxidized ferredoxin $(\mathrm{Fd})$ is reduced by $\mathrm{NADH}$, which is formed during carbon metabolism. Then, the electrons in $\mathrm{Fd}$ are transferred to protons by [FeFe]- $\mathrm{H}_{2}$ ase to form molecular $\mathrm{H}_{2}$ (Figure 1) [52]. 
Recently Schut and Adams proposed a novel model for $\mathrm{H}_{2}$ production for Thermotoga species based on the synergistic effect of NADH and reduced Fd [44]. According to this study, Hzase of T. maritima concurrently oxidizes reduced $\mathrm{Fd}$ and $\mathrm{NADH}$ in a $1: 1$ ratio in order to reduce the $\mathrm{H}^{+}$ions. Ferredoxin is cyclically produced by pyruvate Fd oxidoreductase (POR) during oxidation of pyruvate to acetyl coenzyme A (Figure 1). This mechanism that couples an exoergonic reduction with an endoergonic reduction has been called "bifurcating" [53] and it is proposed to correspond to a novel type of energy conservation. Thus, energy from the oxidation of Fd drives the unfavorable oxidation of NADH in T. maritima [44] and the hyperthermophilic bacterium has the ability to achieve $\mathrm{H}_{2}$ yields close to the Thauer limit. According to this mechanism, $\mathrm{H}_{2}$ production by $\mathrm{H}_{2}$ ase of $T$. neapolitana is influenced by factors that affect either NADH or reduced Fd. Furthermore, the composite mechanism of this $\mathrm{H}_{2}$ ase is consistent with the complexity of the trimeric structure, which is much greater than that of the typical Fd-dependent, single subunit [Fe-Fe]-H2ase found in Clostridium spp. [44].

\section{Production of Lactic Acid and $\mathrm{H}_{2}$ by Capnophilic Lactic Fermentation}

T. neapolitana and the other taxonomically-related species, such as T. maritima, T. petrophila, T. naphtophila, T. caldifontis, T. profunda, Pseudothermotoga thermarum, P. elfii, P. subterranea, $P$. hypogea and $P$. lettingae have been targeted for biological production of $\mathrm{H}_{2}$ because of yields approaching the theoretical maximum value (Thauer limit) of $4 \mathrm{~mol} \mathrm{H}_{2} / \mathrm{mol}$ glucose [46]. According to Figure 1, this result can be achieved only if all of the reducing equivalents from glucose oxidation are used to reduce protons to $\mathrm{H}_{2}$. Nevertheless, as discussed above, in practice these reducing equivalents are also employed for biosynthetic purposes or formation of other fermentation products. Thus, the high $\mathrm{H}_{2}$ yields and low production of biomass that have been reported for T. neapolitana suggest that pyruvate is only partially used in other metabolic transformations under standard operating conditions [54].

Inflow of gases is the most commonly reported method for removing oxygen and $\mathrm{H}_{2}$ from bacterial cultures in closed reactors $[55,56]$. Use of $\mathrm{CO}_{2}$ as gas sparging significantly increases the rate of both glucose consumption and hydrogen production even if there was no improvement of the overall productivity and molar yield that remained substantially unchanged in comparison with $\mathrm{N}_{2}$ [22]. Paradoxically, $\mathrm{CO}_{2}$ stimulated also synthesis of lactic acid. Feeding experiments with labeled precursors clearly proved that at least part of exogenous $\mathrm{CO}_{2}$ is biologically coupled with acetyl-CoA to give lactic acid when the cultures are stripped by $\mathrm{CO}_{2}$ gas or enriched in sodium bicarbonate. The process recycles glycolysis-derived acetyl-CoA or employs exogenous acetate with ATP consumption. In this latter case the overall outcome is a conversion of equimolar concentration of acetate and carbon dioxide into lactic acid according to reaction Equation (3).

$$
\mathrm{CH}_{3} \mathrm{CO}_{2} \mathrm{H}+\mathrm{CO}_{2}+4 \mathrm{H}^{+}+4 e^{-} \rightarrow \mathrm{CH}_{3} \mathrm{CH}(\mathrm{OH}) \mathrm{CO}_{2} \mathrm{H}+\mathrm{H}_{2} \mathrm{O}
$$

The fermentative $\mathrm{CO}_{2}$-dependent synthesis of lactic acid and hydrogen was named capnophilic lactic fermentation (CLF) and, as suggested in Figure 2, it put forward the possibility to fully convert sugar to lactic acid (or other reduced derivatives of pyruvate) without affecting hydrogen synthesis by means of an additional consumption of reducing equivalents deriving from other cellular processes [57]. 


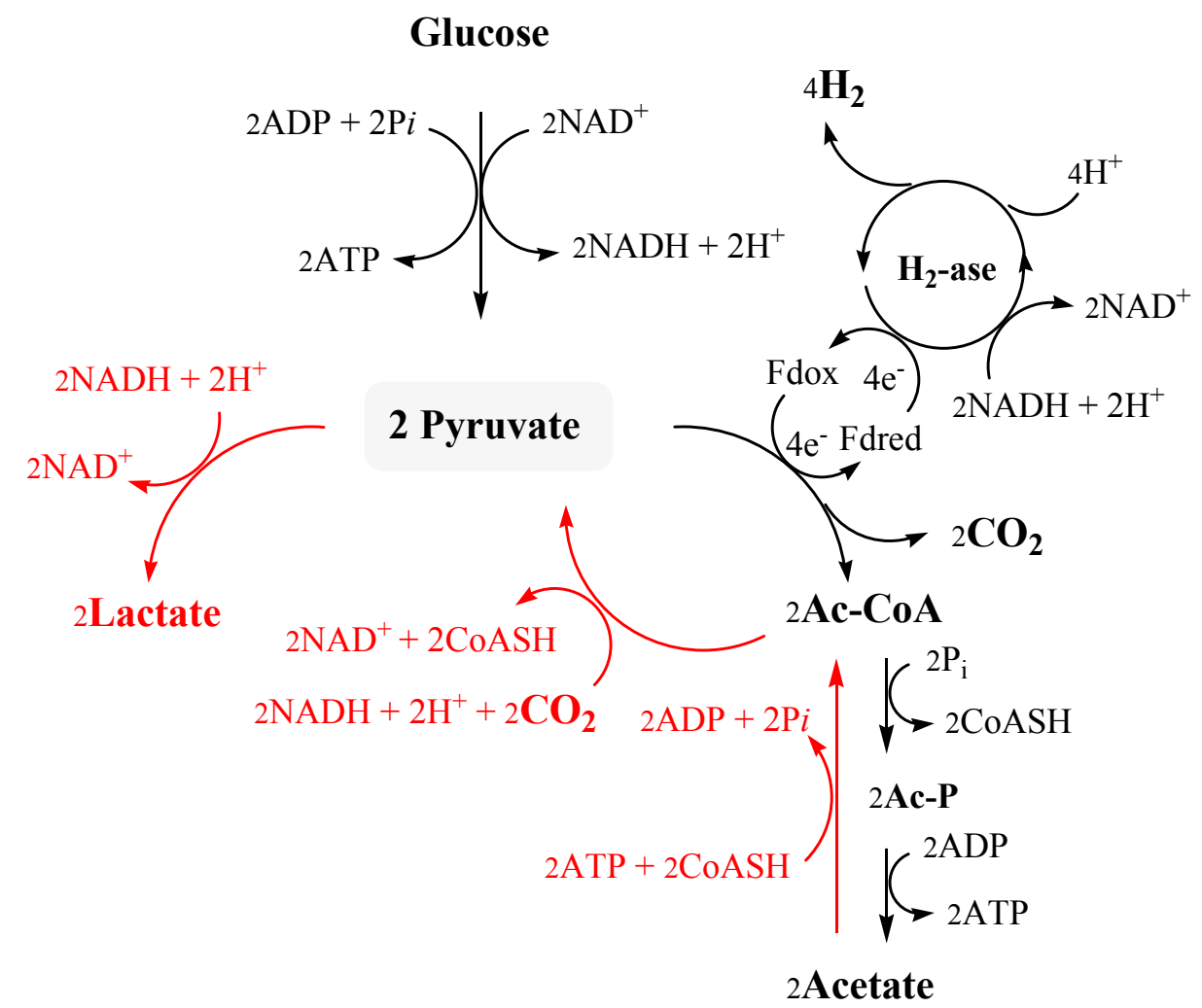

Figure 2. Proposed model of capnophilic lactic fermentation, adapted from [57]. Water is omitted for simplicity.

To date, CLF has been described only in T. neapolitana but the pathway is likely to occur in other species of the order Thermotogales. The key enzyme of the process is a Pyruvate Synthase (also named Pyruvate Oxido-Reductase) that utilizes reduced ferredoxin as source of electrons [57]. In Thermotogales reductive carboxylation of Ac-CoA likely requires the pool of $\mathrm{Fd}$ that is also involved in hydrogen production. Role of Fd as efficient reductant in pyruvate synthesis has been demonstrated in vitro with Clostridium thermoaceticum [58] and suggested in vivo for methanogenic archaea, such as Methanosarcina barkeri [59]. It is noteworthy that the sequence of pyruvate oxido-reductase of this last organism has a good relation to those of T. neapolitana and T. maritima [57]. CLF is an example of biological sequestration of carbon dioxide by coupling with an exogenous substrate (acetate, glucose, etc.) and release of the end-product (lactic acid) outside of the cell. Since T. neapolitana does not convert $\mathrm{CO}_{2}$ to the reduced organic compounds required for cell metabolism, the above mechanism is not related to the autotrophic fixation known in other anaerobes. In fact, unlike known autotrophic [60,61] and heterotrophic [62,63] pathways for carbon dioxide assimilation, the capnophilic metabolism of $T$. neapolitana implies complete excretion of $\mathrm{CO}_{2}$ after fixation in lactic acid and no synthesis of reduced organic compounds required for cell metabolism.

\section{Substrate Metabolism by Thermotoga neapolitana}

As discussed above, extreme thermophiles are capable of producing $\mathrm{H}_{2}$ yields close to the theoretical Thauer limit of $4.0 \mathrm{~mol} \mathrm{H}_{2} / \mathrm{mol}$ of glucose. In addition, the theoretical maximum yield for xylose, sucrose and glycerol are $3.33 \mathrm{~mol} \mathrm{H}_{2} / \mathrm{mol}$ xylose, $8.0 \mathrm{~mol} \mathrm{H}_{2} / \mathrm{mol}$ sucrose and $3.0 \mathrm{~mol} \mathrm{H} / \mathrm{mol}$ 
glycerol under dark fermentation. Glucose is the substrate that gives the highest production of $\mathrm{H}_{2}$ with T. neapolitana. In batch experiments with this sugar, independent studies have reported $\mathrm{H}_{2}$ yield higher than $3.5 \mathrm{~mol} / \mathrm{mol}$ and production rate ranging from 23 to $50 \mathrm{~mL} / \mathrm{L} / \mathrm{h}$ at $\mathrm{pH}$ of 7.5 and temperature of $80{ }^{\circ} \mathrm{C}$ [45,64]. As already mentioned above, the bacterium can also efficiently use a wide range of other substrates ranging from simple to complex sugars including ribose, xylose, fructose, sucrose, maltose, lactose, galactose, starch, and glycogen (Table 1) [21,24,50,65-71].

Waste glycerol from bio-diesel manufacturing is currently considered an attractive and abundant feedstock for fermentation process. Batch tests conducted by Maru et al. [69] have demonstrated that $2.65 \mathrm{~mol}$ of $\mathrm{H}_{2}$ can be produced per mole of glycerol by using the bacterium T. neapolitana at a glycerol concentration of $2.5 \mathrm{~g} / \mathrm{L}$. Ngo and Sim [72] also reported that the bacterium transforms pure glycerol and crude waste glycerol with approximately similar $\mathrm{H}_{2}$ production $(447 \pm 22$ and $437 \pm 21 \mathrm{~mL} / \mathrm{L}$, respectively). According to these authors, these yields are better than those reported with mesophilic bacteria $[73,74]$ and addition of itaconic acid to buffer the culture medium further increased this productivity with both substrates. It is notable that a prediction model built on comparative analysis of the genomes of T. maritima and T. neapolitana put forward that this latter species should not be able to metabolize a number of sugars, including cellotetraose. However, experimental assessment proved that the bacterium grows on this substrate despite that the model predicted an incomplete cellotetraose transport complex. Proteomic analysis of glucose and cellotetraose revealed two possible new gene clusters that may be associated with transport of these sugars [75].

Cappelletti et al. [65] showed that T. neapolitana, T. maritima, T. petrophila and T. naphtophila produce about $2.95 \mathrm{~mol}$ of $\mathrm{H}_{2}$ per mol of glucose equivalent from molasses and $2.5 \mathrm{~mol} \mathrm{of} \mathrm{H}_{2}$ per mol of glucose equivalent from cheese whey, whereas 2.7-2.8 $\mathrm{mol}$ of $\mathrm{H}_{2}$ per mol of glucose equivalent were produced on carrot pulp hydrolysates containing glucose, fructose and sucrose as main sugars [50]. Enzymatic hydrolysis of the polysaccharide fraction prior to fermentation increased the $\mathrm{H}_{2}$ yield of almost $10 \%$ to $2.3 \mathrm{~g} / \mathrm{kg}$ of hydrolyzed carrot pulp. Lignocellulosic substrates (e.g., crop residues) were tested for $\mathrm{H}_{2}$ production with some standard pretreatment to wash out lignin [70,76,77]. Thermo-chemical pretreatment (i.e., heat, ammonia soaking and dilute $\mathrm{H}_{2} \mathrm{SO}_{4}$ soaking) were found to be effective pretreatment techniques to remove lignin and enhance availability of simple sugars for $\mathrm{H}_{2}$ production. According to Ngo et al. [76] $2.8 \mathrm{~mol}$ of $\mathrm{H}_{2}$ per mol of xylose equivalent are produced by T. neapolitana in a $\mathrm{pH}$-controlled continuously stirred anaerobic bioreactor sparged with $\mathrm{N}_{2}$ gas. Similar results have also been reported with rice straw pretreated with ammonia soaking and diluted sulfuric acid [70]. Algal biomass (Chlamydomonas reinhardtii) pretreated by heat-HCl or Termamyl ${ }^{\circledR}$ enzymatic hydrolysis has been also used as substrate of $T$. neapolitana to give $2.5 \mathrm{~mol}$ of $\mathrm{H}_{2}$ per mol of glucose equivalent [71]. Without pretreatment, a slightly lower yield $(2.2 \mathrm{~mol} / \mathrm{mol}$ of glucose equivalent) was produced by fermentation of laminarans derived from the marine diatom Thalassiosira weissflogii [66]. 
Table 1. $\mathrm{H}_{2}$ production from various substrates by hyperthermophilic eubacterium $T$. neapolitana $. \mathrm{B}=$ batch; $\mathrm{FB}=$ fed-batch; $\mathrm{AA}=\mathrm{Acetic}$ acid; LA = Lactic acid; EtOH = Ethanol.

\begin{tabular}{|c|c|c|c|c|c|c|c|c|c|}
\hline Carbon Source & $\begin{array}{c}\text { Substrate } \\
\text { Load }(g / L)\end{array}$ & $\begin{array}{c}\text { Culture } \\
\text { Type }\end{array}$ & $\begin{array}{c}\mathbf{T}\left({ }^{\circ} \mathbf{C}\right) / \text { Start } \\
\text { pH }\end{array}$ & $\begin{array}{c}\text { Mixing Speed } \\
\text { (rpm) }\end{array}$ & $\begin{array}{c}\text { Reactor } \\
\text { Volume (mL) }\end{array}$ & $\begin{array}{c}\text { Working } \\
\text { Volume (mL) }\end{array}$ & $\mathrm{H}_{2}$ Yield & Byproducts & Ref \\
\hline Glucose & 5 & $\mathrm{~B}$ & $80 / 7.5$ & 250 & 3800 & 1000 & $2.8 \mathrm{~mol} \mathrm{H}_{2} / \mathrm{mol}$ glucose & $\mathrm{AA}, \mathrm{LA}, \mathrm{CO}_{2}$ & {$[22]$} \\
\hline Glucose & 5 & B & $80 / 7.1$ & 250 & 2400 & 600 & $3.5 \pm 0.1 \mathrm{~mol} \mathrm{H}_{2} / \mathrm{mol}$ glucose $\mathrm{e}^{a}$ & $\mathrm{AA}, \mathrm{LA}, \mathrm{CO}_{2}$ & {$[45]$} \\
\hline Glucose & 10 & $\mathrm{~B}$ & $72 / 7.0$ & 350 & 2000 & 1000 & $3.5 \mathrm{~mol} \mathrm{H}_{2} / \mathrm{mol}$ glucose & $\mathrm{AA}, \mathrm{LA}, \mathrm{CO}_{2}$ & {$[50]$} \\
\hline Glucose & 20 & B & $72 / 7.0$ & 350 & 2000 & 1000 & $3.4 \mathrm{~mol} \mathrm{H}_{2} / \mathrm{mol}$ glucose & $\mathrm{AA}, \mathrm{LA}, \mathrm{CO}_{2}$ & {$[50]$} \\
\hline Glucose/Fructose 7:3 & 10 & $\mathrm{~B}$ & $72 / 7.0$ & 350 & 2000 & 1000 & $3.3 \mathrm{~mol} \mathrm{H}_{2} / \mathrm{mol}$ glucose & $\mathrm{AA}, \mathrm{LA}, \mathrm{CO}_{2}$ & {$[50]$} \\
\hline Glucose/Fructose 7:3 & 20 & B & $72 / 7.0$ & 350 & 2000 & 1000 & $3.0 \mathrm{~mol} \mathrm{H}_{2} / \mathrm{mol}$ glucose & $\mathrm{AA}, \mathrm{LA}, \mathrm{CO}_{2}$ & {$[50]$} \\
\hline Fructose & 10 & B & $72 / 7.0$ & 350 & 2000 & 1000 & $3.4 \mathrm{~mol} \mathrm{H}_{2} / \mathrm{mol}$ fructose & $\mathrm{AA}, \mathrm{LA}, \mathrm{CO}_{2}$ & {$[50]$} \\
\hline Fructose & 20 & $\mathrm{~B}$ & $72 / 7.0$ & 350 & 2000 & 1000 & $3.2 \mathrm{~mol} \mathrm{H}_{2} / \mathrm{mol}$ fructose & $\mathrm{AA}, \mathrm{LA}, \mathrm{CO}_{2}$ & {$[50]$} \\
\hline Carrot pulp hydrolysate & 10 & B & $72 / 7$ & 350 & 2000 & 1000 & $2.7 \mathrm{~mol} \mathrm{H} / \mathrm{mol}$ glucose & $\mathrm{AA}, \mathrm{LA}, \mathrm{CO}_{2}, \mathrm{EtOH}$ & {$[50]$} \\
\hline Carrot pulp hydrolysate & 20 & $\mathrm{~B}$ & $72 / 7$ & 350 & 2000 & 1000 & $2.4 \mathrm{~mol} \mathrm{H}_{2} / \mathrm{mol}$ glucose & $\mathrm{AA}, \mathrm{LA}, \mathrm{CO}_{2}, \mathrm{EtOH}$ & {$[50]$} \\
\hline Glycerol & 5 & $\mathrm{~B}$ & $75 / 7.5$ & - & 120 & 40 & $2.7 \pm 0.1 \mathrm{~mol} \mathrm{H}_{2} / \mathrm{mol}$ glycerol & $\mathrm{AA}, \mathrm{LA}, \mathrm{CO}_{2}$ & {$[64]$} \\
\hline Molasses & 20 & B & $77 / 8.5$ & 100 & 116 & 40 & $2.6 \pm 0.1 \mathrm{~mol} \mathrm{H}_{2} / \mathrm{mol}$ glucose & $\mathrm{AA}, \mathrm{LA}, \mathrm{CO}_{2}$ & {$[65]$} \\
\hline Cheese whey & 12.5 & B & $77 / 8.5$ & 100 & 116 & 40 & $2.4 \pm 0.1 \mathrm{~mol} \mathrm{H}_{2} / \mathrm{mol}$ glucose & $\mathrm{AA}, \mathrm{LA}, \mathrm{CO}_{2}$ & {$[65]$} \\
\hline Diatom ${ }^{b}$ water soluble sugars & 2 & $\mathrm{~B}$ & $80 / 7.5-8$ & 250 & 3800 & 500 & $1.9 \pm 0.1 \mathrm{~mol} \mathrm{H}_{2} / \mathrm{mol}$ glucose & $\mathrm{AA}, \mathrm{LA}, \mathrm{CO}_{2}$ & {$[66]$} \\
\hline Glucose & 5 & B & $80 / 8.0$ & 200 & 120 & 60 & $3.8 \pm 0.4 \mathrm{~mol} \mathrm{H}_{2} / \mathrm{mol}$ glucose & $\mathrm{AA}, \mathrm{LA}, \mathrm{CO}_{2}$ & {$[67]$} \\
\hline Arabinose & 5 & $\mathrm{~B}$ & $80 / 8.0$ & 200 & 120 & 60 & $3.8 \pm 0.5 \mathrm{~mol} \mathrm{H}_{2} / \mathrm{mol}$ arabinose & $\mathrm{AA}, \mathrm{LA}, \mathrm{CO}_{2}$ & {$[67]$} \\
\hline Xylose & 5 & B & $80 / 8.0$ & 200 & 120 & 60 & $3.4 \pm 0.3 \mathrm{~mol} \mathrm{H}_{2} / \mathrm{mol}$ xylose & $\mathrm{AA}, \mathrm{LA}, \mathrm{CO}_{2}$ & {$[67]$} \\
\hline Potato steam peels & 10 & B & $75 / 6.9$ & 350 & 2000 & 1000 & $3.8 \mathrm{~mol} \mathrm{H} / \mathrm{mol}$ glucose & $\mathrm{AA}, \mathrm{LA}, \mathrm{CO}_{2}$ & {$[68]$} \\
\hline Glycerol & 2.5 & $\mathrm{~B}$ & $80 / 7.3$ & 200 & $120 / 240$ & $25 / 50$ & $2.6 \mathrm{~mol} \mathrm{H}_{2} / \mathrm{mol}$ glycerol & $\mathrm{AA}, \mathrm{LA}, \mathrm{CO}_{2}$ & {$[69]$} \\
\hline Rice straw & 10 & B & $75 / 7.5$ & 150 & 120 & 40 & $2.7 \mathrm{mmol} \mathrm{H} / \mathrm{g}$ straw & - & {$[70]$} \\
\hline Algal $^{c}$ starch & 5 & B & $75 / 7-7.4$ & 150 & 120 & 40 & $2.5 \pm 0.3 \mathrm{~mol} \mathrm{H}_{2} / \mathrm{mol}$ glucose & - & {$[71]$} \\
\hline Glycerol & $1-10$ & $\mathrm{~B}$ & $75 / 7.5$ & - & 120 & 40 & $620 \pm 30 \mathrm{~mL} \mathrm{H}_{2} / \mathrm{L}$ glycerol & $\mathrm{AA}, \mathrm{LA}, \mathrm{CO}_{2}$ & {$[72]$} \\
\hline Xylose & 5 & $\mathrm{~B}$ & $75 / 7.5$ & 300 & 3000 & 1000 & $2.8 \pm 0.1 \mathrm{~mol} \mathrm{H}_{2} / \mathrm{mol}$ xylose & $\mathrm{AA}, \mathrm{LA}, \mathrm{CO}_{2}$ & {$[76]$} \\
\hline
\end{tabular}


Table 1. Cont.

\begin{tabular}{|c|c|c|c|c|c|c|c|c|c|}
\hline Carbon Source & $\begin{array}{c}\text { Substrate } \\
\text { Load }(g / L)\end{array}$ & $\begin{array}{c}\text { Culture } \\
\text { Type }\end{array}$ & $\begin{array}{c}\mathrm{T}\left({ }^{\circ} \mathbf{C}\right) / \text { Start } \\
\text { pH } \\
\end{array}$ & $\begin{array}{c}\text { Mixing Speed } \\
(\mathbf{r p m})\end{array}$ & $\begin{array}{c}\text { Reactor } \\
\text { Volume }(\mathrm{mL})\end{array}$ & $\begin{array}{c}\text { Working } \\
\text { Volume (mL) }\end{array}$ & $\mathbf{H}_{2}$ Yield & Byproducts & Ref. \\
\hline Glucose/Xylose 7:3 & $10-28$ & $\mathrm{~B}$ & $80 / 6.8$ & 350 & 2000 & 1000 & 2.5-3.3 $\mathrm{mol} \mathrm{H}_{2} / \mathrm{mol}$ glucose & $\mathrm{AA}, \mathrm{LA}, \mathrm{CO}_{2}$ & [77] \\
\hline Cellulose & $10-28$ & $\mathrm{~B}$ & $80 / 6.8$ & 350 & 2000 & 1000 & 2.0-3.2 $\mathrm{mol} \mathrm{H}_{2} / \mathrm{mol}$ glucose & $\mathrm{AA}, \mathrm{LA}, \mathrm{CO}_{2}$ & [77] \\
\hline Xylose & 5 & $\mathrm{~B}$ & $75 / 7.0$ & 300 & 3000 & 1000 & $1.8 \pm 0.1 \mathrm{~mol} \mathrm{H}_{2} / \mathrm{mol}$ xylose & $\mathrm{AA}, \mathrm{LA}, \mathrm{CO}_{2}$ & [78] \\
\hline Glucose & 7.5 & B & $77 / 8.5$ & 100 & 119 & 40 & $1.3 \pm 0.1 \mathrm{mmol} \mathrm{H}_{2} / \mathrm{g}$ glucose & $\mathrm{AA}, \mathrm{LA}, \mathrm{CO}_{2}$ & [79] \\
\hline Molasses & 20 & B & $77 / 8.5$ & 100 & 119 & 40 & $1.8 \pm 0.1 \mathrm{~mol} \mathrm{H} / \mathrm{g}$ glucose & $\mathrm{AA}, \mathrm{LA}, \mathrm{CO}_{2}$ & [79] \\
\hline Cheese whey & 12.5 & $\mathrm{~B}$ & $77 / 8.5$ & 100 & 119 & 40 & $1.04 \pm 0.05 \mathrm{~mol} \mathrm{H}_{2} / \mathrm{mol}$ glucose & $\mathrm{AA}, \mathrm{LA}, \mathrm{CO}_{2}$ & [79] \\
\hline Glucose & 5 & FB & $75 / 7.5$ & 300 & 3000 & 1000 & $3.2 \pm 0.2 \mathrm{~mol} \mathrm{H}_{2} / \mathrm{mol}$ glucose & $\mathrm{AA}, \mathrm{LA}, \mathrm{CO}_{2}$ & [80] \\
\hline Xylose & 5 & FB & $75 / 7.5$ & 300 & 3000 & 1000 & $2.2 \pm 0.1 \mathrm{~mol} \mathrm{H}_{2} / \mathrm{mol}$ xylose & $\mathrm{AA}, \mathrm{LA}, \mathrm{CO}_{2}$ & [80] \\
\hline Sucrose & 5 & FB & $75 / 7.5$ & 300 & 3000 & 1000 & $4.9 \pm 0.2 \mathrm{~mol} \mathrm{H} / 2 \mathrm{~mol}$ sucrose & $\mathrm{AA}, \mathrm{LA}, \mathrm{CO}_{2}$ & [80] \\
\hline Glucose & 2.5 & $\mathrm{~B}$ & $77 / 7.5$ & 75 & 160 & 50 & $3.8 \pm 0.3 \mathrm{~mol} \mathrm{H}_{2} / \mathrm{mol}$ glucose & $\mathrm{AA}, \mathrm{LA}, \mathrm{CO}_{2}$ & {$[81]$} \\
\hline Glucose & 5 & $\mathrm{~B}$ & $70 / 8.5$ & 75 & 160 & 50 & $24 \% \mathrm{H}_{2}(v / v)$ headspace $^{d}$ & $\mathrm{CO}_{2}$ & {$[82]$} \\
\hline Glucose & 7 & $\mathrm{~B}$ & $77 / 7.5$ & 150 & 120 & 40 & $3.2 \pm 0.1 \mathrm{~mol} \mathrm{H}_{2} / \mathrm{mol}$ glucose & $\mathrm{AA}, \mathrm{LA}, \mathrm{CO}_{2}$ & [83] \\
\hline Xylose & 4 & B & $77 / 7.5$ & 150 & 120 & 40 & $2.2 \pm 0.1 \mathrm{~mol} \mathrm{H}_{2} / \mathrm{mol}$ xylose & $\mathrm{AA}, \mathrm{LA}, \mathrm{CO}_{2}$ & [83] \\
\hline Glucose & 5 & $\mathrm{~B}$ & $70 / 8.5$ & - & 160 & 50 & $25 \%-30 \% \mathrm{H}_{2}(v / v)$ headspace $^{d}$ & $\mathrm{AA}, \mathrm{LA}, \mathrm{CO}_{2}$ & {$[84]$} \\
\hline Cellulose $^{e}$ & 5 & $\mathrm{~B}$ & $75-80 / 7.5$ & 150 & 120 & 50 & $0.25 \pm 0.01 \mathrm{~mol} \mathrm{H}_{2} / \mathrm{mol}$ glucose & $\mathrm{AA}, \mathrm{CO}_{2}$ & {$[85]$} \\
\hline Cellulose derivative & 5 & B & $75-80 / 7.5$ & 150 & 120 & 50 & $0.77 \pm 0.04 \mathrm{~mol} \mathrm{H}_{2} /$ g glucose & $\mathrm{AA}, \mathrm{CO}_{2}$ & {$[85]$} \\
\hline Cellulose & 5 & $\mathrm{~B}$ & $80 / 7.5$ & 150 & 120 & 40 & $2.2 \mathrm{~mol} \mathrm{H}_{2} / \mathrm{mol}$ glucose & $\mathrm{AA}, \mathrm{CO}_{2}$ & {$[85]$} \\
\hline Starch & 5 & $\mathrm{~B}$ & $75-80 / 7.5$ & 150 & 120 & 50 & $1.4 \pm 0.1 \mathrm{~mL} \mathrm{H}_{2} / \mathrm{g}$ glucose & $\mathrm{AA}, \mathrm{CO}_{2}$ & [85] \\
\hline
\end{tabular}

${ }^{a}$ excluding the estimated contribution from protein; ${ }^{b}$ Thalassiosira weissflogii $;{ }^{c}$ Chlamydomonas reinhardtii; ${ }^{d}$ yield not reported; ${ }^{e}$ Miscanthus giganteus. 
There are conflicting reports on the effect of protein lysates on growth and $\mathrm{H}_{2}$ production by T. neapolitana. Maru et al. [69] noticed that reduced level of yeast extract (YE) negatively affects $\mathrm{H}_{2}$ production but increasing concentration from 2 to $4 \mathrm{~g} / \mathrm{L}$ did not induce significant change in gas evolution. On the contrary, increasing YE concentration from 1 to $4 \mathrm{~g} / \mathrm{L}$ improved biomass and $\mathrm{H}_{2}$ production in cultures of $T$. neapolitana on glycerol as reported by other independent studies [72,73]. No effect is reported through increasing the concentration of protein lysates above $5 \mathrm{~g} / \mathrm{L}$. Cappelletti et al. [65] reported that partial production of $\mathrm{H}_{2}$ can be due to metabolism of tryptone soy broth (TSB) whereas the contribution of YE is null. On the other hand, transformation of peptone, tryptone and $\mathrm{YE}$ yields $10 \%-15 \%$ to the total $\mathrm{H}_{2}$ production according to d'Ippolito et al. [45] and Eriksen et al. [67].

\section{Systems Integration}

According to Levin et al. [86], $\mathrm{H}_{2}$ production by dark fermentation is considered the most practically applicable process for production of the energy carrier. However, as shown in Figure 1, only $2 \mathrm{~mol}$ of carbon from the substrate (i.e., glucose) are fully oxidized to $\mathrm{CO}_{2}$ and only $4 \mathrm{~mol}_{2}$ are formed. Thus, according to the dark fermentation model, a fermentative $\mathrm{H}_{2}$ production can only convert, even in an optimal condition, less than 33\% of the energy from the substrate (e.g., glucose). On the other hand, the transformation efficiency can be significantly improved (theoretically up to $12 \mathrm{~mol} \mathrm{H}_{2}$ per mol of glucose) if a second biological process allows for the complete oxidation of the residual products released by the thermophilic process. In particular, photo-heterotrophic fermentation

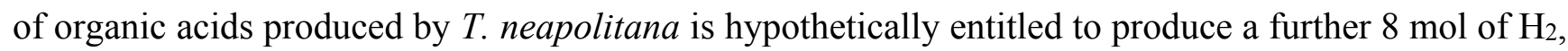
thus reaching the maximum possible yield of $12 \mathrm{~mol}$ of $\mathrm{H}_{2}$.

Purple nonsulphur (PNS) bacteria are a non-taxonomic group of microorganisms that are attractive for the biological production of $\mathrm{H}_{2}$ from biomass (reviewed in [87]). A few studies have also demonstrated that these microorganisms can be successfully integrated into a two-step process to produce $\mathrm{H}_{2}$ in combination with dark fermentation. The first report of a two-stage process with T. neapolitana by Uyar and coworkers [88] showed that Rhodobacter capsulatus effectively produces hydrogen when the concentration of acetate is lower than $60 \mathrm{mM}$ in the spent medium of the thermophilic bacterium. Interestingly these authors also noticed that addition of iron II in the range of 0-29 $\mu \mathrm{M}$ to the culture medium (i.e., to the spent medium of thermophilic bacterium) of $R$. capsulatus increased the hydrogen production in a significant manner $\left(1.37 \mathrm{~L} \mathrm{H}_{2} / \mathrm{L}\right.$ culture in effluent media supplemented with iron and vitamins; $0.30 \mathrm{~L} \mathrm{H}_{2} / \mathrm{L}$ culture in effluent media supplemented only with vitamins). More recently, we have repeated the experiment with $T$. neapolitana and Rhodopseudomonas palustris by replacing the traditional conditions of DF (dark fermentation) with those of CLF (capnophilic lactic fermentation) [89]. To achieve photo-fermentation by a mutant strain of $R$. palustris [90], T. neapolitana was grown under reduced level of $\mathrm{NaCl}$ and nitrogen-containing compounds. According to Uyar et al. [88], the spent broths of the thermophilic bacterium were only supplemented with Fe-citrate and phosphate buffer. The combined microbial system gave 9.4 mol of hydrogen per mole of glucose consumed during the anaerobic process, which is the best production yield so far reported for conventional two-stage batch cultivations [89]. The results also proved that 
CLF can be used for inducing a metabolic switch in T. neapolitana that brings actual improvements of hydrogen yields in combination with photofermentation.

The advantages of using biomass for $\mathrm{H}_{2}$ production range from the mitigation of $\mathrm{CO}_{2}$ and other pollutant emissions, to reduction of environmental and economical costs for disposing wastes. Limitations in use of biomass are mainly due to the seasonal availability of agro wastes, costs of their collection and incomplete use of the organic matter. In this view, microalgal biomass is an attractive alternative since algal cultivation can theoretically run continuously with no restriction due to seasonal cycle and can yield large amounts of biomass of constant composition. Furthermore, fermentation of algal feedstock can be associated with production of biofuels or by-products of high value. T. neapolitana directly produces $\mathrm{H}_{2}$ by fermentation of the biomass of the green alga Chlamydomonas reinhardtii with molar yields $(1.8-2.2 \mathrm{~mol} / \mathrm{mol}$ glucose equivalent) depending on pretreatment methods [71]. T. neapolitana possesses genes encoding both for a 1,3- $\beta$-glucosidase BglB (laminaribiase) and a 1,3- $\beta$-glucanase LamA (laminarinase) that are able to completely degrade chrysolaminarin, the storage polysaccharides of diatoms, to glucose with a synergic action [91,92]. Accordingly, the bacterium fermented the water-soluble fraction of the marine diatom Thalassiosira weissflogii without any pretreatment [66]. Production $(434 \mathrm{~mL} / \mathrm{L}$ in $24 \mathrm{~h} ; 18.1 \mathrm{~mL} / \mathrm{L} / \mathrm{h})$ and yield $(2.2 \mathrm{~mol} \mathrm{H} / \mathrm{mol}$ glu. eq $)$ of $\mathrm{H}_{2}$ on diatom extracts containing $2 \mathrm{~g} / \mathrm{L}$ of sugar equivalent were just slightly lower than those achieved by fermentation of glucose $(809 \mathrm{~mL} / \mathrm{L}$ in $24 \mathrm{~h} ; 33.7 \mathrm{~mL} / \mathrm{L} / \mathrm{h}$; $3.0 \mathrm{~mol} \mathrm{H} / 2 \mathrm{~mol} \mathrm{glu}$ ) and pure chrysolaminarin $(643 \mathrm{~mL} / \mathrm{L}$ in $24 \mathrm{~h} ; 26.8 \mathrm{~mL} / \mathrm{L} / \mathrm{h} ; 3.2 \mathrm{~mol} \mathrm{H} / \mathrm{mol}$ glu. eq).

\section{Bioreactor Configuration}

Several bioreactor configurations such as continuously stirred tank reactors (CSTRs), fluidized bed reactors (FBRs), packed bed reactors (PBRs), up-flow anaerobic sludge blanket (UASB) reactors, anaerobic sequencing batch reactors (AnSBRs), high rate/hybrid reactors, and membrane biological reactors (MBRs) have promising prospects for dark fermentation processes [14]. Table 2 reports the CSTR used for fed-batch and continuous reactors studied for $\mathrm{H}_{2}$ production by suspended and immobilized cells of $T$. neapolitana. CSTRs operate continuously and the bulk inside the reactor is mixed uniformly. However the mixing rate depends on the reactor geometry and power input [93]. CSTRs favor mass transfer among biomass, substrates and gases, and are effective in temperature and pH bulk control. However, CSTR can experience biomass washout, when the loading and the dilution rate increases.

The biomass washout is less probable in attached biomass reactors (e.g., FBRs, PBRs, UASB) where inert material is used to support and contain the bacteria, thus providing a high concentration of cells and, consequently high solids retention time, high organic load, high mass transfer efficiency and high tolerance for shock loads [78,94,95]. Several inert materials have been used successfully as support for T. neapolitana growth, i.e., coir, bagasse, loofah sponge, expanded clay, diatomaceous clay, activated carbon, polysaccharide gels (e.g., alginate, k-carrageenan, agar, chitosan), synthesized materials (e.g., polyvinyl alcohol (PVA), silicone, polyacrylamide, urethane foam and polymethyl methacrylate) [26,96-99], ceramic porous carries (i.e., biomax) [65,79], and porous glass beads [78]. The batch fermentation tests conducted by $\mathrm{Ngo}$ and Bui have shown that the $\mathrm{H}_{2}$ production rate and $\mathrm{H}_{2}$ yield of the immobilized cells reached the highest values of $5.64 \pm 0.19 \mathrm{mmol} \mathrm{H} / \mathrm{L} / \mathrm{h}$ and 
$1.84 \pm 0.1 \mathrm{~mol} \mathrm{H} / \mathrm{mol}$ xylose, respectively, which were 1.7- and 1.3-fold higher than those with free cells [78]. Synthetic hydrogels based on methacrylate derivatives with buffer capacity also effectively supported cell growth and hydrogen production [96,100]. In particular, the use of hydrogel with positive charge and amine groups doubled hydrogen production rate compared with suspension cultures. Both sugar metabolism and hydrogen synthesis were affected positively by neutralization of the

acidic

side-products of the fermentation, i.e., acetate and lactate. The presence of positively charged groups on the inert support proved to be critical to promote the colonization of the polymeric material by a great number of $T$. neapolitana cells laying in a biofilm-like arrangement.

Table 2. Continuous and fed-batch operation in CSTRs for T. neapolitana.

\begin{tabular}{|c|c|c|c|c|c|c|c|}
\hline Substrate & $\begin{array}{c}\text { Reactor } \\
\text { Volume (L) }\end{array}$ & $\begin{array}{c}\text { Working } \\
\text { Volume (L) }\end{array}$ & $\begin{array}{l}\text { Temp. } \\
\left({ }^{\circ} \mathrm{C}\right)\end{array}$ & Culture Type & $\begin{array}{c}\text { Culture } \\
\text { Condition } \\
\end{array}$ & $\mathrm{H}_{2}$ Yield & References \\
\hline $\begin{array}{c}\text { Glucose/Xylose/ } \\
\text { Arabinose }\end{array}$ & 3.0 & 2.75 & 80 & Suspended cells & Fed-batch & $\begin{array}{c}3.8 \pm 0.4 \mathrm{~mol} \mathrm{H}_{2} / \mathrm{mol} \text { glucose; } \\
3.4 \pm 0.3 \mathrm{~mol} \mathrm{H}_{2} / \mathrm{mol} \text { xylose; } \\
3.8 \pm 0.5 \mathrm{~mol} \mathrm{H}_{2} / \mathrm{mol} \text { arabinose }\end{array}$ & {$[67]$} \\
\hline $\begin{array}{c}\text { Glucose/Sucrose/ } \\
\text { Xylose }\end{array}$ & 3.0 & 1.0 & 75 & Suspended cells & Fed-batch & $\begin{array}{c}3.2 \pm 0.16 \mathrm{~mol} \mathrm{H}_{2} / \mathrm{mol} \text { glucose; } \\
4.95 \pm 0.25 \mathrm{~mol} \mathrm{H}_{2} / \mathrm{mol} \text { sucrose; } \\
2.2 \pm 0.11 \mathrm{~mol} \mathrm{H}_{2} / \mathrm{mol} \text { xylose }\end{array}$ & {$[80]$} \\
\hline Xylose & 3.0 & 1.0 & 75 & Immobilized cells & Fed-batch & $1.84 \pm 0.1 \mathrm{~mol} \mathrm{H}_{2} / \mathrm{mol}$ xylose & {$[78]$} \\
\hline $\begin{array}{l}\text { Glucose/Cheese } \\
\text { whey/Molasses }\end{array}$ & 19.0 & 15.0 & 77 & Suspended cells & Continuous & $\begin{array}{c}1.2 \mathrm{mmol} \mathrm{H} / \mathrm{L} / \mathrm{h} \text { for glucose; } \\
0.42 \mathrm{mmol} / \mathrm{L} / \mathrm{h} \text { for cheese whey; } \\
1.3 \mathrm{mmol} / \mathrm{L} / \mathrm{h} \text { for molasses }\end{array}$ & [79] \\
\hline Glucose & - & - & 80 & Immobilized cells & Fed-batch & $3.3 \mathrm{~mol} \mathrm{H}_{2} / \mathrm{mol}$ glucose & [96] \\
\hline
\end{tabular}

\section{Operating Conditions and Kinetics of Thermotoga neapolitana Fermentation}

\subsection{Hydraulic Retention Time (HRT)}

In the dark fermentative $\mathrm{H}_{2}$ production, hydraulic retention time (HRT), organic loading rate (OLR) and $\mathrm{pH}$ are coupled variables since short HRT and high OLR generally correspond to low $\mathrm{pH}$ condition that affects the biomass metabolism. Both high OLR and low HRT represent favorable conditions for $\mathrm{H}_{2}$ production as such operating conditions inhibit other slow growing bacteria, such as methanogens [101]. A HRT in the range of $0.25-60 \mathrm{~h}$ (lower HRT for attached/immobilized biomass and higher HRT for suspended growth biomass) is proved to be suitable for hyperthermophilic dark fermentative $\mathrm{H}_{2}$ production by $T$. neapolitana in batch, fed-batch and continuous bioreactors using a wide range of substrates such as glucose, sucrose, starch, lignocellulose, organic waste and algal starch [102]. T. neapolitana is an exceptionally robust microorganism for $\mathrm{H}_{2}$ production because of its efficient hydrolytic abilities and adaptability to different culture conditions [77]. Nevertheless, production of $\mathrm{H}_{2}$ is optimal only in very restricted range of operating conditions. In particular, the bacterium grows in a wide interval of temperatures (i.e., 55-90 ${ }^{\circ} \mathrm{C}$ ) but the highest $\mathrm{H}_{2}$ production occurs between 75 and $80{ }^{\circ} \mathrm{C}[76]$. 


\subsection{Working $p H$}

As reported above, culture $\mathrm{pH}$ is directly affected by the acidogenic activity. Consequently, $\mathrm{pH}$ control by base addition (e.g., $\mathrm{NaOH}$ ) is critically important to maximize both $\mathrm{H}_{2}$ production and substrate consumption [45,80,81]. Growth of T. neapolitana is inhibited at $\mathrm{pH}$ of 4.5 [82], whereas change from 4.0 to 5.5 induces an increase of $\mathrm{H}_{2}$ content in the headspace from $42 \%$ to $64 \%$ [103]. Nguyen et al. demonstrated that variation of $\mathrm{pH}$ in $T$. neapolitana cultures from 5.5 to 7.0 enhances cumulative $\mathrm{H}_{2}$ production from 125 to $198 \mathrm{~mL} \mathrm{H} / \mathrm{L}$ medium, but further increase to 8.0-9.0 leads to total decline in the biogas evolution [83]. At laboratory scale, the strict control of $\mathrm{pH}$ has also suggested the use of compounds with increased buffer capacity such as diacid/monoacid phosphate $\left(\mathrm{HPO}_{4}^{-2} / \mathrm{H}_{2} \mathrm{PO}_{4}^{-}\right)$, tris (hydroxymethyl) aminomethane (TRIS), 3-( $N$-morpholino) propanesulfonic acid (MOPS), piperazine- $N, N^{\prime}$-bis(2-ethanesulfonic) acid (PIPES), and 4-(2-hydroxyethyl)-1-piperazineethanesulfonic acid (HEPES) [77,81,82,84]. For large scale application the use of these chemicals is probably economically prohibitive but similar effects could be achieved by use of more convenient products (e.g., $\mathrm{CO}_{2}$ ).

\subsection{Temperature}

The primary fermentation products for $T$. neapolitana across the permissive growth temperature range are $\mathrm{H}_{2}, \mathrm{CO}_{2}$, acetate and small amounts of lactate. Two independent studies on the influence of temperature on $\mathrm{H}_{2}$ production of $T$. neapolitana and T. maritima support a direct correlation with $\mathrm{H}_{2}$ production and bacterial growth [81,85]. Munro et al. reported that rate and amount of glucose consumption and $\mathrm{H}_{2}$ formation increased by arising the operating temperature from 60 to $77^{\circ} \mathrm{C}$, but there was no significant difference from 77 to $85^{\circ} \mathrm{C}$ [81]. Although production of acetate and lactate indicated a difference between 77 and $85{ }^{\circ} \mathrm{C}$, a comparison of the molar yields acetate/glucose and lactate/glucose for the operating temperatures between 65 and $85^{\circ} \mathrm{C}$ suggested no significant change in molar yield for the two organic acids.

\subsection{Partial Pressure}

The total and partial pressure of gas inside the reactor influences the biomass growth and product formation. According to Schonheit and Schafer [104], $\mathrm{H}_{2}$ itself inhibits the process in a batch reactor. Van Niel et al. reported that $\mathrm{H}_{2}$ partial pressure less than $20 \mathrm{kPa}$ is required for reactor operating at high temperature $\left(>70{ }^{\circ} \mathrm{C}\right)$ [20]. Partial pressure of $\mathrm{H}_{2}$ above $20 \mathrm{kPa}$ reverses the metabolic pathway, thereby facilitating the production of more reduced products such as acetone, ethanol, lactate, butanol and alanine $[11,50,105]$. Experimental data show that use of pure nitrogen as gas sparging and high ratio between headspace volume/culture volume can contain the partial pressure of $\mathrm{H}_{2}$ below the critical limit in cultures of $T$. neapolitana [45,67,81]. Increase in yield and production of $\mathrm{H}_{2}$ are reported by $\mathrm{N}_{2}$ sparging compared to no sparging condition [45,83]. The tolerance of T. neapolitana to oxygen is matter of debate. Van Ooteghem et al. described significant improvement of $\mathrm{H}_{2}$ production under microaerobic condition [82,84], whereas Eriksen et al., in line with other studies, reported that $T$. neapolitana can tolerate only low oxygen partial pressure (1\% or $1.2 \mathrm{kPa})$ and 
found that $6 \% \mathrm{O}_{2}(7.2 \mathrm{kPa})$ inside the reactor completely inhibits $\mathrm{H}_{2}$ production and reduces glucose consumption from 12 to $4 \mu \mathrm{mol} / \mathrm{h}[106]$.

\subsection{Mathematical Modeling and Kinetics}

Metabolic transformation of glucose by $T$. neapolitana can be effectively described with the Equation (4).

$$
\mathrm{C}_{6} \mathrm{H}_{12} \mathrm{O}_{6}+(2-m) \mathrm{H}_{2} \mathrm{O} \rightarrow(4-m) \mathrm{H}_{2}+(2-m) \mathrm{AA}+(2-m) \mathrm{CO}_{2}+m \mathrm{LA}
$$

where $m$ is a stoichiometric coefficient [22].

A majority of studies have either adapted or modified exiting mathematical (or empirical) models to describe the experimental results [107]. Gompertz empirical model (Equaton (5)) and International Water Association (IWA) anaerobic digestion model No. 1 (ADM1) are the most popular models to simulate dark fermentation. The Gompertz model is particularly used to estimate the maximum hydrogen production potential and to determine the lag phase for $\mathrm{H}_{2}$ production [108] but it does not allow the process kinetics to be addressed because of the exclusion of operating conditions (e.g., substrate type and concentration, $\mathrm{pH}$, temperature, and partial pressure of gas mixture) that regulate the fermentation reaction [108].

$$
H(t)=P * \exp \left\{-\exp \left[\frac{R_{m} e}{P}(\lambda-t)+1\right]\right\}
$$

where

$H(t)=$ Cumulative $\mathrm{H}_{2}$ production $(\mathrm{mL} / \mathrm{L})$

$P=\mathrm{H}_{2}$ production potential $\left(\mathrm{mL} \mathrm{H}_{2}\right)$

$R_{m}=$ Maximum $\mathrm{H}_{2}$ production rate $\left(\mathrm{mL} \mathrm{H}_{2} / \mathrm{h}\right)$

$t=$ Incubation/cultivation time (h)

$\lambda=$ Duration of the lag phase (h)

On the other hand, ADM1 is a complete and comprehensive kinetic model based on Monod kinetic Equations (6) [109-112] and has been used often to model DF reactions [79,113,114].

$$
\mu=\frac{\mu_{\max } S}{k_{S}+S}
$$

where

$\mu=$ specific growth rate of biomass $\left(\mathrm{h}^{-1}\right)$

$\mu_{\max }=$ maximum specific growth rate of biomass $\left(\mathrm{h}^{-1}\right)$

$k_{s}=$ semi saturation constant $(\mathrm{g} / \mathrm{L}) ; k_{s}$ equals the substrate concentration at which $\mu$ equals $1 / 2 \mu_{\max }$

$S=$ substrate concentration $(\mathrm{g} / \mathrm{L})$

The ADM1-based model and Gompertz empirical model have been extensively used to study $\mathrm{H}_{2}$ production by fermentative process, but to date there are only two studies with $T$. neapolitana. In pure culture on glucose at $77^{\circ} \mathrm{C}$, Yu and Drapcho [114] reported maximum specific maximum growth rate $\left(\mu_{\max }\right)$ of $0.94 \mathrm{~h}^{-1}$ and semi saturation constant $\left(k_{s}\right)$ of $0.57 \mathrm{~g}$ sugar/L when $\mathrm{H}_{2}$ and biomass product yields were $0.0286 \mathrm{~g} \mathrm{H}_{2} / \mathrm{g}$ glucose and $0.248 \mathrm{~g}$ biomass $/ \mathrm{g}$ glucose, respectively. More recently, 
Frascari et al. [79] have studied the kinetic parameters for T. neapolitana grown on glucose, molasses and cheese whey by suspended or immobilized cells. The $\mu_{\max }$ value with immobilized bacteria $\left(0.09 \pm 0.05 \mathrm{~h}^{-1}\right.$ for glucose, $0.19 \pm 0.02 \mathrm{~h}^{-1}$ for molasses and $0.042 \pm 0.007 \mathrm{~h}^{-1}$ for cheese whey) was found to be significantly higher than with suspended cells $\left(0.024 \pm 0.005 \mathrm{~h}^{-1}\right.$ for glucose, $0.055 \pm 0.005 \mathrm{~h}^{-1}$ for molasses and $0.033 \pm 0.006 \mathrm{~h}^{-1}$ for cheese whey). On the contrary, the semi saturation constant $\left(k_{s}\right)$ was $0.09 \pm 0.05 \mathrm{~g}$ sugar/L for glucose, $0.6 \pm 0.2 \mathrm{~g}$ sugar/L for molasses and $1.2 \pm 0.3 \mathrm{~g}$ sugar $/ \mathrm{L}$ for cheese whey in the immobilized systems and $1.1 \pm 0.3 \mathrm{~g}$ sugar/L for glucose, $0.2 \pm 0.05 \mathrm{~g}$ sugar/L for molasses and $1.5 \pm 0.5 \mathrm{~g}$ sugar/L for cheese whey with bacterial suspensions [79].

\section{Conclusions}

Among the various technologies, fermentation has many advantages for the biological production of $\mathrm{H}_{2}$ and is theoretically feasible for large-scale application particularly from the fermentation of solid wastes $[115,116]$. Extensive research in the last decades has shown the promising prospect of using pure cultures of the bacterium T. neapolitana. Like other hyperthermophilic process, the technology is readily used at laboratory scale with high production rate, low energy demand, easy operation and sustainability. On the contrary little has been done in terms of comparison of cost and effectiveness between T. neapolitana and traditional processes that use fossil fuel for production of hydrogen.

T. neapolitana has also shown great potential for other applications such as recovery of byproducts with potential economic value in the market i.e., lactic acid. Introduction of capnophilic process for the simultaneous production of $\mathrm{H}_{2}$ and lactic acid is very promising and could significantly influence the future of agro-waste management. Clearly, further research is needed to optimize the operating parameters and reactor configurations and more experiments are needed to verify process kinetics and full-scale applicability. Nevertheless, fermentation of organic material by the thermophilic bacterium could be the beachhead of a complete conversion process that generates $\mathrm{H}_{2}$ only as a first step.

Agro-food wastes and algal biomass seem to be attractive substrates for fermentation by T. neapolitana and thus are considered as feedstock for comprehensive development of biorefineries. Moreover, coupling of T. neapolitana-based transformation with other biological processes also seems very promising. In this view, chemotrophic production of hydrogen by hyperthermophilic bacteria has already shown great potential in association with both microalgal cultivations and photofermentation by purple nonsulphur bacteria. Finally, considerable enhancement of the fermentative capacity of T. neapolitana can be also expected by metabolic engineering and physiological manipulations of strains, as well as by improvement in reactor configurations [1,117]. In fact, for example the unexpected success of CLF suggests that a huge unexplored gene pool available in nature, with great potential for $\mathrm{H}_{2}$ production, is yet to be discovered [118].

\section{Acknowledgments}

This work was funded by the Italian Ministry of Education, University and Research (MIUR) through the project "Integrated exploitation of algal biomass in the energy supply chain (SIBAFEQ)" (PON01_02740) and by CNR through the project "Energy from Renewable Sources (EFOR)". The authors also acknowledge the assistance and support of the Erasmus Mundus Joint Doctorate 
program $\mathrm{ETeCoS}^{3}$ (Environmental Technologies for Contaminated Solids, Soils and Sediments) under the EU grant agreement FPA No 2010-0009.

\section{Author Contributions}

Nirakar Pradhan and Laura Dipasquale carried out bibliographic search; Nirakar Pradhan, Laura Dipasquale and Angelo Fontana carried out data analysis; Laura Dipasquale and Angelo Fontana wrote the manuscript; Giuliana d'Ippolito, Antonio Panico, Piet N. L. Lens and Giovanni Esposito corrected the manuscript and improved the discussion.

\section{Conflicts of Interest}

The authors declare no conflict of interest.

\section{References}

1. Hallenbeck, P.C.; Benemann, J.R. Biological $\mathrm{H}_{2}$ production; fundamentals and limiting processes. Int. J. Hydrog. Energy 2002, 27, 1185-1193.

2. Nath, K.; Das, D. Improvement of fermentative hydrogen production: Various approaches. Appl. Microbiol. Biotechnol. 2004, 65, 520-529.

3. Fan, Y.; Zhang, Y.; Zhang, S.; Hou, H.; Ren, B. Efficient conversion of wheat straw wastes into biohydrogen gas by cow dung compost. Bioresour. Technol. 2006, 97, 500-505.

4. Ghimire, A.; Frunzo, L.; Pirozzi, F.; Trably, E.; Escudie, R.; Lens, P.N.L.; Esposito, G. A review on dark fermentative biohydrogen production from organic biomass: Process parameters and use of by-products. Appl. Energy 2015, 144, 73-95.

5. Guo, X.M.; Trably, E.; Angenent, L.T.; Karim, K.; al-Dahhan, M.H.; Wrenn, B.; Latrille, E.; Carrère, H.; Steyer, J. Hydrogen production from agricultural waste by dark fermentation: A review. Int. J. Hydrog. Energy 2010, 35, 10660-10673.

6. Kotsopoulos, T.A.; Fotidis, I.A.; Tsolakis, N.; Martzopoulos, G.G. BioH2 production from pig slurry in a CSTR reactor system with mixed cultures under hyperthermophilic temperature $\left(70{ }^{\circ} \mathrm{C}\right)$. Biomass Bioenergy 2009, 33, 1168-1174.

7. Sinha, P.; Pandey, A. An evaluative report and challenges for fermentative $\mathrm{bioH}_{2}$ production. Int. J. Hydrog. Energy 2011, 36, 7460-7478.

8. Vijayaraghavan, K.; Ahmad, D. Biohydrogen generation from palm oil mill effluent using anaerobic contact filter. Int. J. Hydrog. Energy 2006, 31, 1284-1291.

9. Wukovits, W.; Drljo, A.; Hilby, E.; Friedl, A. Integration of biohydrogen production with heat and power generation from biomass residues. Chem. Eng. Trans. 2013, 35, 1003-1008.

10. Djomo, S.N.; Blumberga, D. Comparative life cycle assessment of three biohydrogen pathways. Bioresour. Technol. 2011, 102, 2684-2694.

11. Angenenta, L.T.; Karima, K.; Al-Dahhana, M.H.; Brian, A.; Wrennb, B.A.; Domíguez-Espinosad, R. Production of bioengineering and biochemical's from industrial and agricultural wastewater. Trends Biotechnol. 2004, 22, 477-485. 
12. Elsharnouby, O.; Hafez, H.; Nakhla, G.; el Naggar, M.H. A critical literature review on bioH 2 production by pure cultures. Int. J. Hydrog. Energy 2013, 38, 4945-4966.

13. Amend, J.P.; Shock, E.L. Energetics of overall metabolic reactions of thermophilic and hyperthermophilic Archea and Bacteria. Microbiol. Rev. 2001, 25, 175-243.

14. Krishna, R.H. Review of research on bioreactors used in wastewater treatment for production of bioH $_{2}$ : Future fuel. Int. J. Sci. Invent. Today 2013, 2, 302-310.

15. Hafez, H.; Nakhla, G.; el Naggar, H. Biological $\mathrm{H}_{2}$ production. In Handbook of $\mathrm{H}_{2}$ Energy; Sherif, S.A., Ed.; CRC Press: Boca Raton, FL, USA, 2012.

16. Verhaart, M.R.; Bielen, A.A.; Oost, J.V.D.; Stams, A.J.; Kengen, S.W. Hydrogen production by hyperthermophilic and extremely thermophilic bacteria and archaea: Mechanisms for reductant disposal. Environ. Technol. 2010, 31, 993-1003.

17. Zhang, T.; Liu, H.; Fang, H.H.P. Biohydrogen production from starch in wastewater under thermophilic condition. J. Environ. Manag. 2003, 69, 149-156.

18. Islam, R.; Cicek, N.; Sparling, R.; Levin, D. Influence of initial cellulose concentration on the carbon flow distribution during batch fermentation by Clostridium thermocellum ATCC 27405. Appl. Microbiol. Biotechnol. 2009, 82, 141-148.

19. Liu, Y.; Yu, P.; Song, X.; Qu, Y. $\mathrm{H}_{2}$ production from cellulose by co-culture of Clostridium thermocellum JN4 and Thermoanaerobacterium thermosaccharolyticum GD17. Int. J. Hydrog. Energy 2008, 33, 2927-2933.

20. Van Niel, E.W.J.; Claassen, P.A.M.; Stams, A.J.M. Substrate and product inhibition of $\mathrm{H}_{2}$ production by the extreme thermophile, Caldicellulosiruptor saccharolyticus. Biotech. Bioeng. 2003, 81, 255-262.

21. Cappelletti, M.; Zannoni, D.; Postec, A.; Ollivier, B. Members of the order Thermotogales: From microbiology to hydrogen production. In Microbial BioEnergy: Hydrogen Production; Zannoni, D., de Philippis, R., Eds.; Springer: New York, NY, USA, 2014; Volume 38, pp. 197-224.

22. Dipasquale, L.; d'Ippolito, G.; Fontana, A. Capnophilic lactic fermentation and hydrogen synthesis by Thermotoga neapolitana: An unexpected deviation from the dark fermentation model. Int. J. Hydrog. Energy 2014, 39, 4857-4862.

23. Belkin, S.; Wirsen, C.O.; Jannasch, H.W. A new sulfur-reducing, extremely thermophilic eubacterium from a submarine thermal vent. Appl. Environ. Microbiol. 1986, 51, 1180-1185.

24. Jannasch, H.W.; Huber, R.; Belkin, S.; Stetter, K.O. Thermotoga neapolitana sp. nov. of the extremely thermophilic, eubacterial genus Thermotoga. Arch. Microbiol. 1988, 150, 103-104.

25. Nesbo, C.L.; Bradnan, D.N.; Adebusuyi, A.; Dlutek, M.; Petrus, A.K.; Foght, J.; Doolittle, W.F.; Noll, K.M. Mesotoga prima gen. nov., sp. nov., the first described mesophilic species of the Thermotogales. Extremophiles 2012, 16, 387-393.

26. Angel, A.M.; Brunene, M.; Baumeister, W. The functional properties of Omp $\beta$, the regularly arrayed porin of the hyperthermophilic bacterium Thermotoga neapolitana. FEMS Microbiol. Lett. 1993, 109, 231-236.

27. Huber, R.; Langworthy, T.A.; Konig, H.; Thomm, M.; Woese, C.R.; Sleytr, U.B.; Stetter, K.O. Thermotoga maritima sp. nov. represents a new genus of unique extremely thermophilic eubacteria growing up to $90^{\circ} \mathrm{C}$. Arch. Microbiol. 1986, 144, 324-333. 
28. Rachel, R.; Engel, A.M.; Huber, R.; Stetter, K.O.; Baumeister, W. A porin-type protein is the main constituent of the cell envelope of the ancestral bacterium Thermotoga maritima. FEBS Lett. 1990, 262, 64-68.

29. Kuwabara, T.; Igarashi, K. Microscopic studies on Thermosipho globiformans implicate a role of the large periplasm of Thermotogales. Extremophiles 2012, 16, 863-870.

30. Choi, K.-W.; Seo, J.Y.; Park, K.-M.; Park, C.-S.; Cha, J. Characterization of glycosyl hydrolase family $3 \beta$ - $N$-acetylglucosaminidases from Thermotoga maritima and Thermotoga neapolitana. J. Biosci. Bioeng. 2009, 108, 455-459.

31. Choi, K.-H.; Hwang, S.; Lee, H.-S.; Cha, J. Identification of an extracellular thermostable glicosyl hydrolase family 13 a-amylase from Thermotoga neapolitana. J. Microbiol. 2011, 49, 628-634.

32. Dipasquale, L.; Gambacorta, A.; Siciliano, R.A.; Mazzeo, M.F.; Lama, L. Purification and biochemical characterization of a native invertase from the hydrogen-producing Thermotoga neapolitana. Extremophiles 2009, 13, 345-354.

33. Kang, L.; Park, K.M.; Choi, K.H.; Park, C.S.; Kim, G.E.; Kim, D.; Cha, J. Molecular cloning and biochemical characterization of a heat-stable pullulanase type I from Thermotoga neapolitana. Enzym. Microb. Technol. 2011, 48, 260-266.

34. Lama, L.; Tramice, A.; Finore, I.; Anzelmo, G.; Calandrelli, V.; Pagnotta, E.; Tommonaro, G.; Poli, A.; di Donato, P.; Nicolaus, B.; et al. Degradative actions of microbial xylanolytic activities on hemicelluloses from rhizome of Arundo donax. AMB Express 2014, 4, 55.

35. Liebl, W.G.; Winterhalter, C.; Baumeister, W.; Armbrech, M.; Valdez, M. Xylanase attachment to the cell wall of the hyperthermophilic bacterium Thermotoga maritima. J. Bacteriol. 2008, 190, 1350-1358.

36. Okazaki, F.; Nakashima, N.; Ogino, C.; Tamaru, Y.; Kondo, A. Biochemical characterization of a thermostable $\beta$-1,3-xylanase from the hyperthermophilic Eubacterium, Thermotoga neapolitana strain DSM 4359. Appl. Microbiol. Biotechnol. 2013, 97, 6749-6757.

37. Pozzo, T.; Pasten, J.L.; Karlsson, E.N.; Logan, D.T. Structural and functional analyses of $\beta$-glucosidase 3B from Thermotoga neapolitana: A thermostable three-domain representative of glycoside hydrolase 3. J. Mol. Biol. 2010, 397, 724-739.

38. Schumann, J.; Wrba, A.; Jaenicke, R.; Stetter, K.O. Topographical and enzymatic characterization of amylases from the extremely thermophilic eubacterium Thermotoga maritima. FEBS Lett. 1991, 282, 122-126.

39. Yun, B.Y.; Jun, S.Y.; Kim, N.A.; Yoom, B.Y.; Piao, S.; Park, S.H.; Jeong, S.H.; Lee, H.; Ha, N.C. Crystal structure and thermostability of a putative a-glucosidase from Thermotoga neapolitana. Biochem. Biophys. Res. Commun. 2011, 416, 92-98.

40. Latif, H.; Lerman, J.A.; Portnoy, V.A.; Tarasova, Y.; Nagarajan, H. The Genome Organization of Thermotoga maritima reflects its lifestyle. PLoS Genet. 2013, 9, e1003485.

41. Bhandari, V.; Gupta, R.S. Molecular signatures for the phylum (class) Thermotogae and a proposal for its division into three orders (Thermotogales, Kosmotogales ord. nov. and Petrotogales ord. nov.) containing four families (Thermotogaceae, Fervidobacteriaceae fam.nov., Kosmotogaceae fam. nov. and Petrotogaceae fam. nov.) and a new genus Pseudothermotoga gen. nov. with five new combinations. Antonie Leeuwenhoek 2014, 105, 143-168. 
42. Ravot, G.; Magot, M.; Fardeau, M.L.; Patel, B.K.C.; Prensier, G.; Egan, A.; Garcia, J.L.; Ollivier, B. Thermotoga elfii Sp-Nov, a novel thermophilic bacterium from an african oil-producing well. Int. J. Syst. Bacteriol. 1995, 45, 308-314.

43. Schroder, C.; Selig, M.; Schonheit, P. Glucose fermentation to acetate, $\mathrm{CO}_{2}$ and $\mathrm{H}_{2}$ in the anaerobic hyperthermophilic eubacterium Thermotoga maritima-involvement of the Embden-Meyerhof pathway. Arch. Microbiol. 1994, 161, 460-470.

44. Schut, G.J.; Adams, M.W. The iron-H2ase of Thermotoga maritima utilizes ferredoxin and NADH synergistically: A new perspective on anaerobic $\mathrm{H}_{2}$ production. J. Bacteriol. 2009, 191, 4451-4457.

45. D’Ippolito, G.; Dipasquale, L.; Vella, F.M.; Romano, I.; Gambacorta, A.; Cutignano, A.; Fontana, A. $\mathrm{H}_{2}$ metabolism in the extreme thermophile Thermotoga neapolitana. Int. J. Hydrog. Energy 2010, 35, 2290-2295.

46. Thauer, R.K.; Jungerman, K.; Decker, K. Energy conservation in chemotrophic anaerobic bacteria. Bacteriol. Rev. 1977, 41, 100-180.

47. Anshuman, K.; Mike, M.; Brenda, J. H2: The energy source for the 21st century. Technovation 2005, 25, 569-585.

48. Khanna, N.; Das, D. BioH 2 production by dark fermentation. WIREs Energy Environ. 2013, 2, 401-421.

49. Wu, S.Y.; Hung, C.H.; Lin, C.N.; Chen, H.W.; Lee, A.S.; Chang, J.S. Fermentative $\mathrm{H}_{2}$ production and bacterial community structure in high-rate anaerobic bioreactors containing silicone immobilized and self-flocculated sludge. Biotechnol. Bioeng. 2006, 93, 934-946.

50. De Vrije, T.; Budde, M.A.W.; Lips, S.J.; Bakker, R.R.; Mars, A.E.; Claassen, P.A.M. $\mathrm{H}_{2}$ production from carrot pulp by the extreme thermophiles Caldicellulosiruptor saccharolyticus and Thermotoga neapolitana. Int. J. Hydrog. Energy 2010, 35, 13206-13213.

51. Albertini, M.; Vallese, F.; Valentin, M.; Berto, P.; Giacometti, G.M.; Costantini, P.; Carbonera, D. The proton iron-sulfur cluster environment of the [FeFe]-hydrogenase maturation protein HydF from Thermotoga neapolitana. Int. J. Hydrog. Energy 2014, 39, 18574-18582.

52. Oh, Y.K.; Raj, S.M.; Jung, G.Y.; Park, S. Current status of the metabolic engineering of microorganisms for bioH2 production. Bioresour. Technol. 2011, 102, 8357-8367.

53. Li, F.; Hinderberger, J.; Seedorf, H.; Zhang, J.; Buckel, W.; Thauer, R.K. Coupled ferredoxin and crotonyl coenzyme A (CoA) reduction with NADH catalyzed by the butyryl-CoA deH2ase/Etf complex from Clostridium kluyveri. J. Bacteriol. 2008, 190, 843-850.

54. Frock, A.D.; Notey, J.S.; Kelly, R.M. The genus Thermotoga: Recent developments. Environ. Tech. 2010, 31, 1169-1181.

55. Mizuno, O.; Dinsdale, R.; Hawkes, F.; Hawkes, D.; Noike, T. Enhancement of hydrogen production from glucose by nitrogen gas sparging. Bioresour. Technol. 2000, 73, 59-65.

56. Valdez, I.; Rios, E.; Carmona, A.; Muñoz, K.; Poggi, H. Improvement of biohydrogen production from solid wastes by intermittent venting and gas flushing of batch reactors headspace. Environ. Sci. Technol. 2006, 40, 3409-3415.

57. D'Ippolito, G.; Dipasquale, L.; Fontana, A. Recycling of carbon dioxide and acetate as lactic acid by the hydrogen-producing bacterium Thermotoga neapolitana. ChemSusChem 2014, 7, 2678-2683. 
58. Furdui, C.; Ragsdale, S.W. The role of pyruvate ferredoxin oxidoreductase in pyruvate synthesis during autotrophic growth by the Wood-Ljungdahl pathway. J. Biol. Chem. 2000, 275, 28494-28499.

59. Bock, A.K.; Kunow, J.; Glasemacher, J.; Schönheit, P. Catalytic properties, molecular composition and sequence alignments of pyruvate: Ferredoxin oxidoreductase from the methanogenic archaeon Methanosarcina barkeri (strain Fusaro). Eur. J. Biochem. 1996, 237, 35-44.

60. Berg, I.A.; Kockelkorn, D.; Ramos-vera, W.H.; Say, R.F.; Zarzychi, J.; Hugler, M.; Alber, B.E.; Fuchs, G. Autotrophic carbon fixation in archaea. Nat. Rev. Microbial. 2010, 8, 447-460.

61. Braakman, R.; Smith, E. The emergence and early evolution of biological carbon-fixation. PLoS Comput. Biol. 2012, 8, e1002455.

62. Krebs, H.A. Carbon dioxide assimilation in heterotrophic organisms. Nature 1941, 147, 560-563.

63. Werkman, C.H.; Wood, H.G. Heterotrophic assimilation of carbon dioxide. Adv. Enzymol. Relat. Areas Mol. Biol. 2006, 2, 135-179.

64. Ngo, T.A.; Kim, M.S.; Sim, S.J. High-yield bioH2 production from biodiesel manufacturing waste by Thermotoga neapolitana. Int. J. Hydrog. Energy 2011, 36, 5636-5642.

65. Cappelletti, M.; Bucchi, G.; Mendes, J.D.S.; Alberini, A.; Fedi, S.; Bertin, L.; Frascari, D. $\mathrm{BioH}_{2}$ production from glucose, molasses and cheese whey by suspended and attached cells of four hyperthermophilic Thermotoga strains. J. Chem. Technol. Biotechnol. 2012, 87, 1291-1301.

66. Dipasquale, L.; d'Ippolito, G.; Gallo, C.; Vella, F.M.; Gambacorta, A.; Picariello, G.; Fontana, A. $\mathrm{H}_{2}$ production by the thermophilic eubacterium Thermotoga neapolitana from storage polysaccharides of the $\mathrm{CO}_{2}$-fixing diatom Thalassiosira weissflogii. Int. J. Hydrog. Energy 2012, 37, 12250-12257.

67. Eriksen, N.T.; Leegaard Riis, M.; Kyndby Holm, N.; Iversen, N. H2 synthesis from pentose and biomass in Thermotoga spp. Biotechnol. Lett. 2011, 33, 293-300.

68. Mars, A.E.; Veuskens, T.; Budde, M.A.W.; van Doeveren, P.F.N.M.; Lips, S.J.; Bakker, R.R.; de Vrije, T.; Claassen, P.A.M. $\mathrm{BioH}_{2}$ production from untreated and hydrolyzed potato steam peels by the extreme thermophiles Caldicellulosiruptor saccharolyticus and Thermotoga neapolitana. Int. J. Hydrog. Energy 2010, 35, 7730-7737.

69. Maru, B.T.; Bielen, A.A.M.; Kengen, S.W.M.; Constanti, M.; Medina, F. $\mathrm{BioH}_{2}$ production from glycerol using Thermotoga spp. Energy Procedia 2012, 29, 300-307.

70. Nguyen, T.A.D.; Kim, K.R.; Kim, M.S.; Sim, S.J. Thermophilic $\mathrm{H}_{2}$ fermentation from Korean rice straw by Thermotoga neapolitana. Int. J. Hydrog. Energy 2010, 35, 13392-13398.

71. Nguyen, T.A.D.; Kim, K.R.; Nguyen, M.T.; Kim, M.S.; Kim, D.; Sim, S.J. Enhancement of fermentative $\mathrm{H}_{2}$ production from green algal biomass of Thermotoga neapolitana by various pretreatment methods. Int. J. Hydrog. Energy 2010, 35, 13035-13040.

72. Ngo, T.N.; Sim, S.J. Dark fermentation of $\mathrm{H}_{2}$ from waste glycerol using hyperthermophilic eubacterium Thermotoga neapolitana. Environ. Prog. Sustain. Energy 2012, 31, 466-473.

73. Ito, T.; Nakashimada, Y.; Senba, K.; Matsui, T.; Nishio, N. H2 and ethanol production from Glycerol-containing wastes discharged after biodiesel manufacturing process. J. Biosci. Bioeng. 2005, 100, 260-265. 
74. Pott, R.W.M.; Howe, C.J.; Dennis, J.S. Photofermentation of crude glycerol from biodiesel using Rhodopseudomonas palustris: Comparison with organic acids and the identification of inhibitory compounds. Bioresour. Technol. 2013, 130, 725-730.

75. Munro S.A.; Choe, L.; Zinder, S.H.; Lee, K.H.; Walker, L.P. Proteomic and physiological experiments to test Thermotoga neapolitana constraint-based model hypotheses of carbon source utilization. Biotechnol. Prog. 2012, 28, 312-318.

76. Ngo, T.A.; Nguyen, T.H.; Bui, H.T.V. Thermophilic fermentative $\mathrm{H}_{2}$ production from xylose by Thermotoga neapolitana DSM 4359. Renew. Energy 2012, 37, 174-179.

77. De Vrije, T.; Bakker, R.R.; Budde, M.A.W.; Lai, M.H.; Mars, A.E.; Claassen, P.A.M. Efficient $\mathrm{H}_{2}$ production from the lignocellulosic energy crop miscanthus by the extreme thermophilic bacteria Caldicellulosiruptor saccharolyticus and Thermotoga neapolitana. Biotechnol. Biofuels 2009, 2, 12.

78. Ngo, T.A.; Bui, H.T.V. $\mathrm{BioH}_{2}$ Production using immobilized cells of hyperthermophilic eubacterium Thermotoga neapolitana on porous glass beads. J. Technol. Innov. Renew. Energy 2013, 2, 231-238.

79. Frascari, D.; Cappelletti, M.; Mendes, J.D.S.; Alberini, A.; Scimonelli, F.; Manfreda, C.; Longanesi, L.; Zannoni, D.; Pinelli, D.; Fedi, S. A kinetic study of $\mathrm{bioH}_{2}$ production from glucose, molasses and cheese whey by suspended and attached cells of Thermotoga neapolitana. Bioresour. Technol. 2013, 147, 553-561.

80. Ngo, T.A.; Kim, M.S.; Sim, S.J. Thermophilic $\mathrm{H}_{2}$ fermentation using Thermotoga neapolitana DSM 4359 by fed-batch culture. Int. J. Hydrog. Energy 2011, 36, 14014-14023.

81. Munro, S.A.; Zinder, S.H.; Walker, L.P. The fermentation stoichiometry of Thermotoga neapolitana and influence of temperature, oxygen, and $\mathrm{pH}$ on $\mathrm{H}_{2}$ production. Biotechnol. Progress 2009, 25, 1035-1042.

82. Van Ooteghem, S.A.; Jones, A.; van der Lelie, D.; Dong, B.; Mahajan, D. $\mathrm{H}_{2}$ production and carbon utilization by Thermotoga neapolitana under anaerobic and microaerobic growth conditions. Biotechnol. Lett. 2004, 26, 1223-1232.

83. Nguyen, T.A.D.; Han, S.J.; Kim, J.P.; Kim, M.S.; Oh, Y.K.; Sim, S.J. H2 production by the hyperthermophilic eubacterium, Thermotoga neapolitana, using cellulose pretreated by ionic liquid. Int. J. Hydrog. Energy 2008, 33, 5161-5168.

84. Van Ooteghem, S.A.; Beer, S.K.; Yue, P.C. $\mathrm{H}_{2}$ production by the thermophilic bacterium Thermotoga neapolitana. Appl. Biochem. Biotechnol. 2002, 98, 177-189.

85. Nguyen, T.A.D.; Kim, J.P.; Kim, M.S.; Oh, Y.K.; Sim, S.J. Optimization of $\mathrm{H}_{2}$ production by hyperthermophilic eubacteria, Thermotoga maritima and Thermotoga neapolitana in batch fermentation. Int. J. Hydrog. Energy 2008, 33, 1483-1488.

86. Levin, D.B.; Pitt, L.; Love, M. $\mathrm{BioH}_{2}$ production: Prospects and limitations to practical application. Int. J. Hydrog. Energy 2004, 29, 173-185.

87. Basak, N.; Das, D. The prospect of purple non-sulfur (PNS) photosynthetic bacteria for hydrogen production: The present state of the art. World J. Microbiol. Biotechnol. 2006, 23, 31-42.

88. Uyar, B.; Schumacher, M.; Gebicki, J.; Modigell, M. Photoproduction of hydrogen by Rhodobacter capsulatus from thermophilic fermentation effluent. Bioprocess Biosyst. Eng. 2009, 32, 603-606. 
89. Dipasquale L.; Adessi, A.; d'Ippolito, G.; Rossi, F.; Fontana, A.; de Philippis, R. Introducing capnophilic lactic fermentation in a combined dark-photo fermentation process: A route to unparalleled $\mathrm{H}_{2}$ yields. Appl. Microbiol. Biotechnol. 2015, 99, 1001-1010.

90. Adessi, A.; McKinlay, J.B.; Harwood, C.S.; de Philippis, R. A Rhodopseudomonas palustris nifA $*$ mutant produces $\mathrm{H}_{2}$ from $\mathrm{NH}_{4}{ }^{+}$-containing vegetable wastes. Int. J. Hydrog. Energy 2012, 37, 15893-15900.

91. Zverlov, V.V.; Volkov, I.Y.; Velikodvorskaya, T.V.; Schwarz, W.H. Highly thermostable endo-1,3-b-glucanase (chrysolaminaranase) LamA from Thermotoga neapolitana: Nucleotide sequence of the gene and characterization of the recombinant gene product. Microbiology 1997, 143, 1701-1708.

92. Zverlov, V.V.; Volkov, I.Y.; Velikodvorskaya, T.V.; Schwarz, W.H. Thermotoga neapolitana bglB gene, upstream of lamA, encodes a highly thermostable $\beta$-glucosidase that is a laminaribiase. Microbiology 1997, 143, 3537-3542.

93. Li, R.Y.; Zhang, T.; Fang, H.H.P. Characteristics of a phototrophic sludge producing $\mathrm{H}_{2}$ from acetate and butyrate. Int. J. Hydrog. Energy 2008, 33, 2147-2155.

94. Malina, J.F.; Poland, F.G. Design of Anaerobic Processes for Treatment of Industrial and Municipal Wastes; Technomic Publishing Co., Inc.: Lanchester, UK, 1992.

95. Mohan, S.V.; Rao, N.C.; Prasad, K.K.; Madhavi, B.T.V.; Sarma, P.N. Treatment of complex chemical effluents by sequencing batch reactor (SBR) with aerobic suspended growth configuration. Process Biochem. 2005, 40, 1501-1508.

96. Basile, M.A.; Carfagna, C.; Cerruti, P.; d'Avala, G.G.; Fontana, A.; Gambacorta, A.; Malinconico, M.; Dipasquale, L. Continuous hydrogen production by immobilized cultures of Thermotoga neapolitana on an acrylic hydrogel with $\mathrm{pH}$-buffering properties. RSC Adv. 2012, 2, 3611-3614.

97. Chang, J.S.; Lee, K.S.; Lin, P.J. BioH 2 production with fixed-bed bioreactors. Int. J. Hydrog. Energy 2002, 27, 1167-1174.

98. Kumar, N.; Das, D. Continuous $\mathrm{H}_{2}$ production by immobilized Enterobacter cloacae IIT-BT 08 using lignocellulosic materials as solid matrices. Enzym. Microb. Technol. 2001, 29, 280-287.

99. Wu, K.J.; Chang, J.S. Batch and continuous fermentative production of $\mathrm{H}_{2}$ with anaerobic sludge entrapped in a composite polymeric matrix. Process Biochem. 2007, 42, 279-284.

100. Basile, M.A.; Carfagna, C.; Dipasquale, L.; Fontana, A.; Gambacorta, A.; d'Ayala, G.G.; Malinconico, M.; Cerruti, P. Development of novel immobilizing hydrogels for thermophilic hydrogen production. In Hydrogen Production: Prospects and Processes; Nova Science Publishers Inc.: Hauppauge, NY, USA, 2011; Volume 13, pp. 401-411.

101. Yang, P.; Zhang, R.; McGarvey, J.A.; Benemann, J.R. $\mathrm{BioH}_{2}$ production from cheese processing wastewater by anaerobic fermentation using mixed microbial communities. Int. J. Hydrog. Energy 2007, 32, 4761-4771.

102. Kim, S.H.; Han, S.K.; Shin, H.S. Optimization of continuous $\mathrm{H}_{2}$ fermentation of food waste as a function of solids retention time independent of hydraulic retention time. Process Biochem. 2008, 43, 213-218.

103. Fang, H.H.P.; Liu, H. Granulation of $\mathrm{H}_{2}$-producing acidogenic sludge. In Proceeding of the 9th World Congress Anaerobic Digestion Part 2, Antwerp, Belgium, 2-6 September 2001; Volume 2, pp. 527-532. 
104. Schonheit, P.; Schafer, T. Metabolism of hyperthermophiles. World J. Microbiol. Biotechnol. 1995, 11, 26-57.

105. Hawkes, F.R.; Hussy, I.; Kyazza, G.; Dinsdale, R.; Hawkes, D.L. Continuous dark fermentative $\mathrm{H}_{2}$ production by mesophilic microflora: Principles and progress. Int. J. Hydrog. Energy 2007, 32, 172-184.

106. Eriksen, T.N.; Niels, N.T.; Iversen, N. $\mathrm{H}_{2}$ production in anaerobic and microaerobic Thermotoga neapolitana. Biotechnol. Lett. 2008, 30, 103-109.

107. Gadhe, A.; Sonawane, S.S.; Varma, M.N. Optimization of conditions for $\mathrm{H}_{2}$ production from complex dairy wastewater by anaerobic sludge using desirability function approach. Int. J. Hydrog. Energy 2013, 38, 6607.

108. Gadhamshetty, V.; Arudchelvam, Y.; Nirmalakhandan, N.; Johnson, D.C. Modeling dark fermentation for bioH $\mathrm{H}_{2}$ production: ADM1-based model vs. Gompertz model. Int. J. Hydrog. Energy 2010, 35, 470-490.

109. Batstone, D.J.; Keller, J.; Angelidaki, I.; Kalyuzhnyi, S.V. Anaerobic Digestion Model No. 1 (ADM1). In IWA Task Group for Mathematical Modeling of Anaerobic Digestion Processes; IWA Publishing: London, UK, 2002.

110. Castello, E.; García, C.; Santos, Y.; Iglesias, T.; Paolino, G.; Wenzel, J.; Borzacconi, L. Feasibility of bioH$_{2}$ production from cheese whey using a UASB reactor: Links between microbial community and reactor performance. Int. J. Hydrog. Energy 2009, 34, 5674-5682.

111. Fuentes, M.; Scenna, N.J.; Aguirre, P.A. Modeling of $\mathrm{H}_{2}$ production in biofilm reactors: Application of the Anaerobic Digestion Model 1. Hyfusen 2011, 01-223.

112. Paulo, C.I.; Maggio, J.A.D.; Diaz, M.S.; Ruggeri, B. Modeling and parameter estimation in biofuel discontinuous production by $\mathrm{H}_{2}$ forming bacteria (HFB). Chem. Eng. Trans. 2013, 32, 1033-1038.

113. Wang, J.; Wan, W. Kinetic models for fermentative $\mathrm{H}_{2}$ production: A review. Int. J. Hydrog. Energy 2009, 34, 3313.

114. Yu, X.; Drapcho, C. $\mathrm{H}_{2}$ production by the hyperthermophilic bacterium Thermotoga neapolitana using agricultural-based carbon and nitrogen sources. Biol. Eng. Trans. 2011, 4, 101-112.

115. Kovacs, K.L.; Maróti, G.; Rákhelya, G. A novel approach for biohydrogen production. Int. J. Hydrog. Energy 2006, 31, 1460-1468.

116. Munoz-Páez, K.M.; Ríos-Leal, E.; Valdez-Vazquez, I. Re-fermentation of washed spent solids from batch hydrogenogenic fermentation for additional production of biohydrogen from the organic fraction of municipal solid waste. J. Environ. Manag. 2012, 95, S355-S359.

117. Mathews, J.; Wang, G. Metabolic pathway engineering for enhanced bioH2 production. Int. J. Hydrog. Energy 2009, 34, 7404-7416.

118. Show, K.Y.; Lee, D.J.; Tay, J.H.; Lin, C.Y.; Chang, J.S. BioH2 production: Current perspectives and the way forward. Int. J. Hydrog. Energy 2012, 37, 15616-15631.

(C) 2015 by the authors; licensee MDPI, Basel, Switzerland. This article is an open access article distributed under the terms and conditions of the Creative Commons Attribution license (http://creativecommons.org/licenses/by/4.0/). 